This PDF is a selection from a published volume from the National Bureau of Economic Research

Volume Title: Seeking a Premier Economy: The Economic Effects of British Economic Reforms, 1980-2000

Volume Author/Editor: David Card, Richard Blundell and Richard B. Freeman, editors

Volume Publisher: University of Chicago Press

Volume ISBN: 0-226-09284-4

Volume URL: http://www.nber.org/books/card04-1

Conference Date: December 8-9, 2000

Publication Date: June 2004

Title: Mobility and Joblessness

Author: Paul Gregg, Stephen Machin, Alan Manning

URL: http://www.nber.org/chapters/c6752 


\title{
Mobility and Joblessness
}

\author{
Paul Gregg, Stephen Machin, and Alan Manning
}

\section{Introduction}

The perceived impact of location on economic opportunity has been a constant refrain in discussions of the economic performance of the United Kingdom for as long as anyone can remember and the source of much feeling that the British economy is not as flexible as it should be. In the $1980 \mathrm{~s}$ the preoccupation was with the so-called "North-South divide," the contrast between the booming southern part of England with its economy based on the service sector and the depressed Northern regions whose economies were struggling to deal with the decimation of the heavy manufacturing on which they had previously depended in the Thatcher recession of the early 1980s. The North-South divide appeared to diminish in the recession of the early $1990 \mathrm{~s}$, but there have been concerns in some quarters that it is reemerging in recent years.

More recently attention has moved away from differences in economic opportunity at the level of very aggregated regions and toward differences at a much more local level (e.g., see Noble et al. 2000). A Cabinet Office report to the Prime Minister (Cabinet Office 1999, 11) noted that "the disparity within regions is at least as great as that between them." For example,

Paul Gregg is a reader in economics at the University of Bristol. Stephen Machin is professor of economics at University College London and the Centre for Economic Performance at the London School of Economics. Alan Manning is professor of economics in the department of economics and the Centre for Economic Performance at the London School of Economics.

We would like to thank Jordi Blanes-i-Vidal and Steve Gibbons for research assistance on this project, Savvas Savouri for providing some of the migration data, Abigail McKnight for providing the data on the origins and destinations of university graduates, and David Card, Steve Pischke, and other conference participants for their comments. 
inner London has some of the highest unemployment rates in the whole country at the same time that the shops of Oxford Street have the highest level of vacancies in the country. After his victory in the 1997 election, Tony Blair set up the Social Exclusion Unit, which cuts across traditional ministerial boundaries to deal with the consequences of when people or areas suffer from a combination of linked problems such as unemployment, poor skills, low incomes, poor housing, high crime environments, bad health and family breakdown. Its existence is based on the idea that there is a need for joined up solutions to joined up problems. While there have always been rich and poor neighborhoods, there is also a feeling that the poorest areas have not shared in the growing prosperity of the country. At its most melodramatic, one might argue that Britain is ghettoizing.

Many commentators have felt that the structure of the U.K. housing market contributes to some of the spatial problems that the United Kingdom faces. In the early 1980s Hughes and McCormick (1981) argued that the level of subsidy and the allocation of housing within the council sector made council tenants very immobile and made the emergence of regions or pockets of unemployment more likely. In the 1990s Muellbauer and his coauthors (e.g., Muellbauer and Murphy 1997; Cameron and Muellbauer 1998) argued that the cult of owner-occupation together with financial market deregulation makes housing prices in the United Kingdom follow speculative bubbles that interfere with the workings of the real economy. And, more recently, Oswald $(1996,1997)$ has suggested that home ownership is bad (or sometimes it is private renting that is good) for unemployment. ${ }^{1}$

The plan of this paper is as follows. In the next section, we present evidence on the extent of regional inequalities in the United Kingdom and whether they have worsened over time. Regional inequalities in Britain are substantial, but they have always been so, and there is no strong evidence of a dramatic change over time. However, we also emphasize how successful the United Kingdom has been in creating an integrated national labor market for graduates and argue that the key to understanding how we can reduce regional inequalities lies, in part, in understanding the differences between the graduate and nongraduate labor markets. A number of possible reasons for the successful creation of an integrated graduate labor market are considered.

First, we show that regional migration rates are much higher for graduates than the less educated and that this is likely to be the main reason why the graduate labor market is more integrated. But why should migration rates be so much higher for graduates? It is argued that the returns to migration may well be smaller for graduates than others so that any explana-

1. An earlier version of this paper did contain a section evaluating this hypothesis, but the evidence for it in the United Kingdom was so weak that this has been dropped from the final version. 
tion must be based on differing costs of migration. We consider a number of hypotheses.

First, it may be that the process of leaving home to go to college provides a psychological break with the region of one's childhood, and we do present evidence that graduates are less likely to take a first job in their parental region if they moved away to college.

Second, we go on to consider the determinants of residential mobility. Most existing studies have emphasized that residential and regional mobility in the United Kingdom is much lower than in the United States but that the unemployed are more likely to move than the employed. We argue that it is extremely rare for the unemployed to move regions without first having found a job. As vacancies for the less skilled tend to be advertised only locally, it is then very hard for the less skilled to move regions, and this is a major reason for the lower migration rates of the less skilled. When the labor market is booming, employers in the most prosperous regions may be forced to advertise more widely to recruit even unskilled workers. We then get the pattern (seen in the data) that it is easier to move to a highemployment region when times are good, although, ironically, it tends to be only when times are bad that anyone starts worrying about the low levels of regional mobility.

We also consider the impact of housing tenure on mobility. We argue that the apparent negative impact of being in council housing on regional mobility may have less to do with the rent subsidy associated with council housing and more to do with the demographic profile of tenants.

The paper then moves on to consider inequalities between neighborhoods. Using census data from 1981 and 1991 we show that there was little change in the of distribution of unemployment and nonemployment rates across neighborhoods. While there are big differences between rich and poor areas, there seems to be little evidence that these have worsened over time. We also consider one of the biggest changes to affect neighborhoods in this period, the sale of council houses. We show that, even in the neighborhoods with the highest rates of council housing, something like 20 percent of the stock was sold. Those likely to buy were much more likely to be better off (e.g., older households, those with dual earners, the more educated, and those from higher social classes). But we could find no evidence that sales of council houses resulted in a change in the social composition of a neighborhood other than the obvious impact of the change in housing tenure.

\subsection{Regional Inequalities}

Regional differences in economic performance are well known (see Blackaby and Manning 1990; Hughes and McCormick 1994; Evans and McCormick 1994) and will only briefly be summarized here. Panel A of 
A
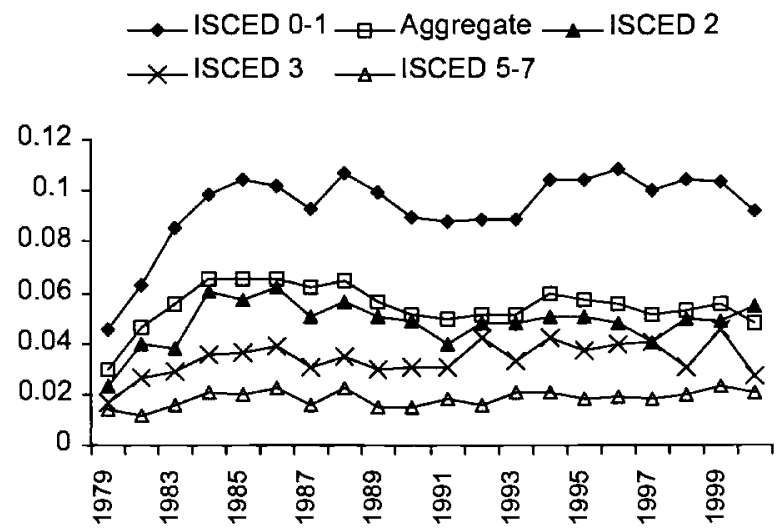

B
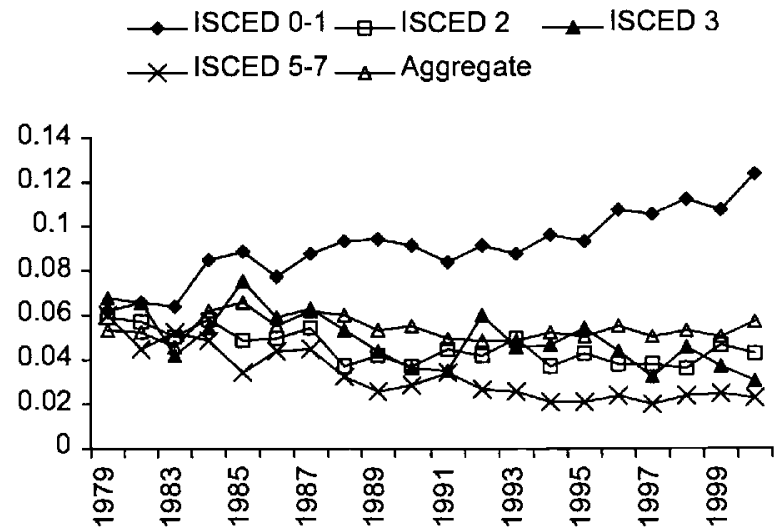

Fig. 9.1 $A$, The standard deviation of regional relative male employmentpopulation ratios; $B$, the standard deviation of regional relative female employmentpopulation ratios; $C$, the standard deviation of regional male unemployment rates; $D$, the standard deviation of regional female unemployment rates

Notes: $A$, This graph plots the population-weighted standard deviation of the employmentpopulation ratio relative to the aggregate employment-population ratio across regions; $C$, these are the labor-force weighted standard deviations in the regional unemployment rates.

figure 9.1 presents the evolution of the standard deviation of the male employment-population ratio across regions. Several points stand out. First, there was a large rise in the standard deviation in the early 1980s, and although there has been a decline since, the gap is still wider than it was in the late 1970s. Second (as has been pointed out by McCormick, 1997, among others), regional differences are entirely the result of differences in employment-population ratios among less-skilled workers. ${ }^{2}$ Panel B of

2. One should remember that the increase in educational attainment over time means that the low-skilled group is decreasing in importance. 
C
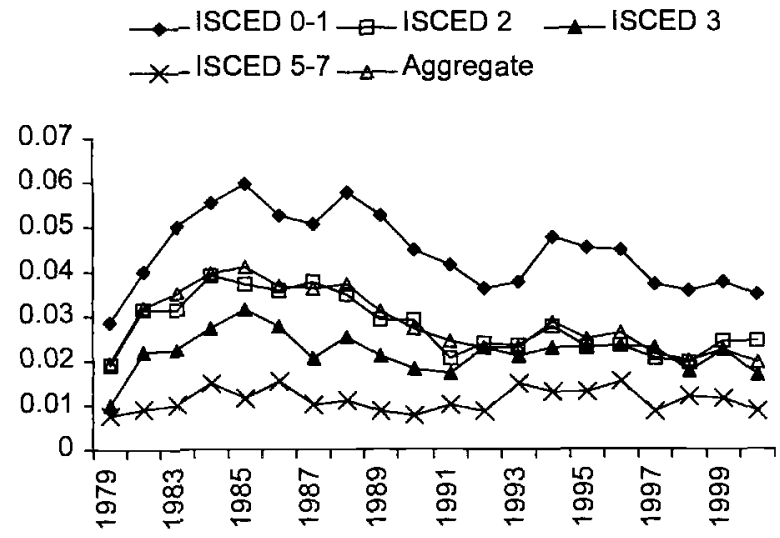

D
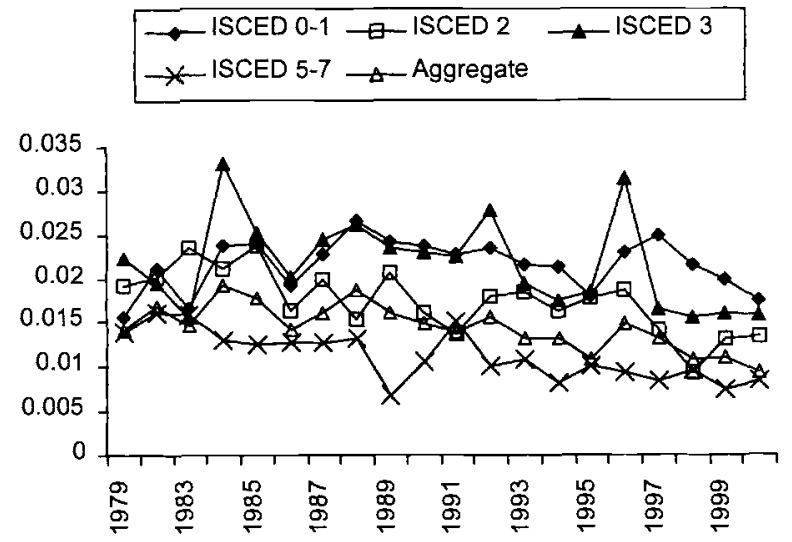

Fig. 9.1 (cont.)

figure 9.1 presents the standard deviation of relative regional female employment-population ratios, and panels $\mathrm{C}$ and $\mathrm{D}$ of figure 9.1 do the same for regional male and female unemployment rates. In all cases, the limited extent of regional inequalities among the educated is very clear. ${ }^{3}$ For example, in 1999 the male employment-population ratio for university graduates (International Standard Classification of Education [ISCED] 5-7) ranged from 86 percent in South Yorkshire to 95 percent in the Southeast (excluding London), while that for those without educational qualifica-

3. In this paper we classify education using the ISCED measure: In the British education system ISCED $0-1$ corresponds to those without any formal qualifications, ISCED 2 corresponds to those who left school at age sixteen but with some qualifications (" $O$ " levels or General Certificate of Secondary Education [GCSEs]), ISCED 3 corresponds to those who left school at age eighteen with " $A$ " levels, and ISCED 5-7 corresponds to those with some tertiary education (mostly college graduates). 
Persistence in Regional Unemployment Rates

\begin{tabular}{llc}
\hline & \multicolumn{2}{c}{ Correlation Coefficient } \\
\cline { 3 - 3 } Country/Education & $79-99$ & 8999 \\
\hline United Kingdom & & \\
All & 0.77 & 0.86 \\
ISCED 0-1 & 0.77 & 0.86 \\
ISCED 2 & 0.58 & 0.69 \\
ISCED 3 & 0.56 & 0.46 \\
ISCED 5-7 & 0.28 & -0.13 \\
United States & & \\
All & 0.38 & 0.55 \\
\hline
\end{tabular}

Note: These are the correlation coefficients for the unemployment rates across eighteen U.K. regions and fifty U.S. states.

tions ranged from 56 percent in Tyne and Wear to 82 percent in the Southeast (excluding London).

There are other ways of seeing that the United Kingdom has successfully created an integrated labor market for grad uates. The previous figure shows us the variation in unemployment rates but says nothing about persistence. Table 9.1 presents some simple correlations to shed light on this issue. ${ }^{4} \mathrm{Re}-$ gional unemployment rates show a high degree of correlation over this period, but this is almost entirely the consequence of high correlations among the less educated. As a reference point (though differences in geographical size makes comparisons problematic) we also report the correlation in unemployment rates across U.S. states. The U.K. graduate labor market appears to be more integrated than the aggregate U.S. labor market. There is nothing intrinsic to the British character that makes an integrated national labor market an impossibility: One should look for more mundane explanations.

So far we have documented the extent of regional inequalities but without identifying their nature. Most popular discussion thinks of regional inequalities in terms of the North-South divide, but it is not obvious that this is the most striking geographical distinction one could make. Figure 9.2 presents the evolution in the unemployment rates and employmentpopulation ratios for the North and the South and also for the metropolitan and nonmetropolitan areas. In many ways the gap between the metropolitan and nonmetropolitan areas is as striking as that of the North-South divide.

4. It might be better to estimate dynamic responses to regional shocks along the lines of Blanchard and Katz (1992) or Decressin and Fatas (1995). However, lack of data makes it impossible to do this disaggregated by education, and the correlations presented in table 9.1 should be thought of as a poor substitute. 

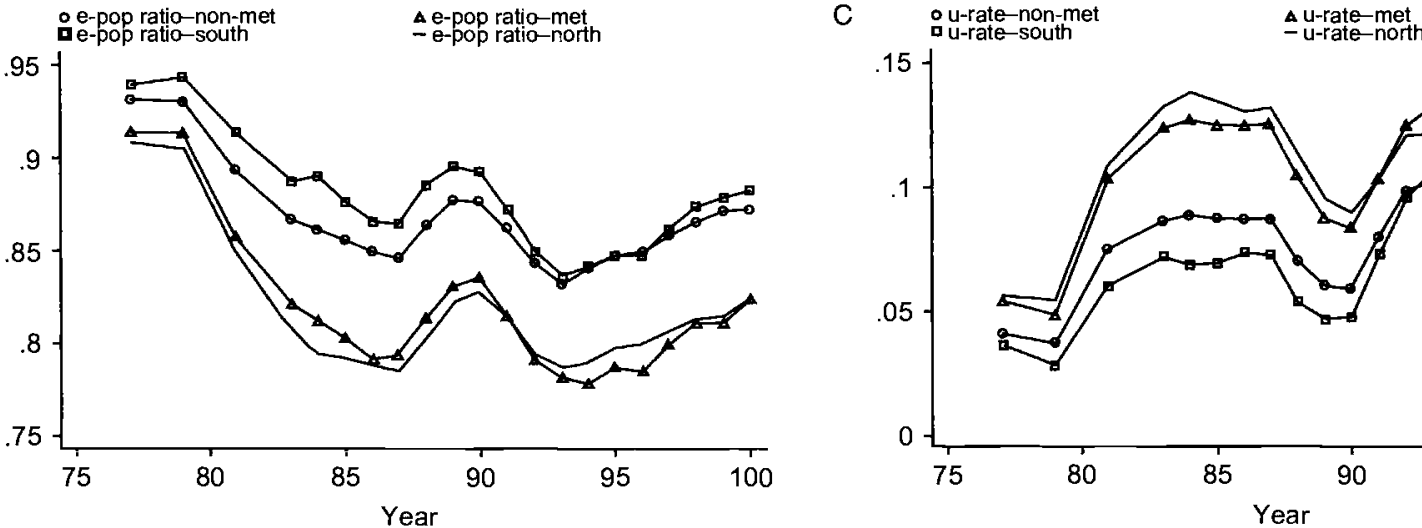

B
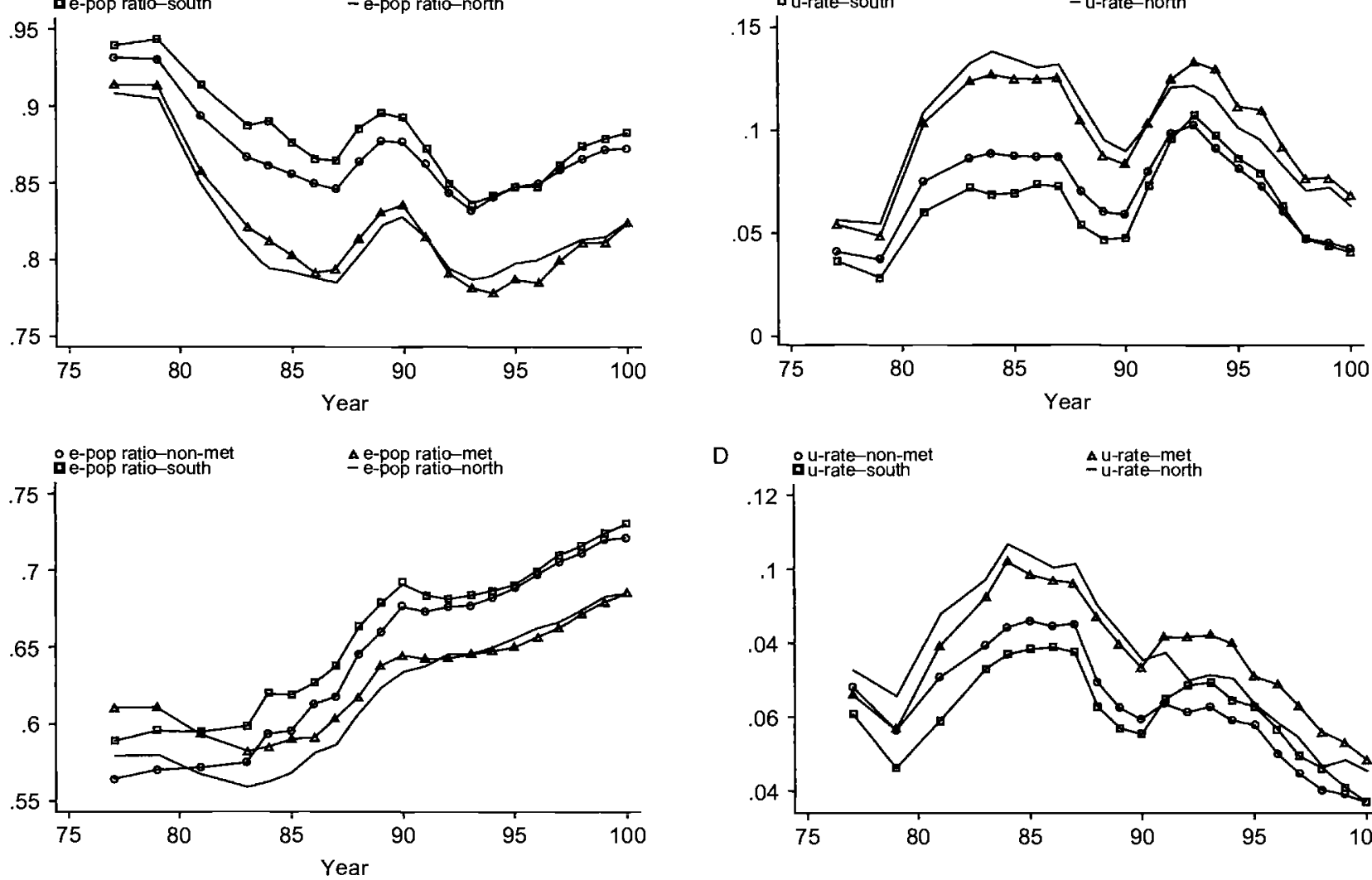

D

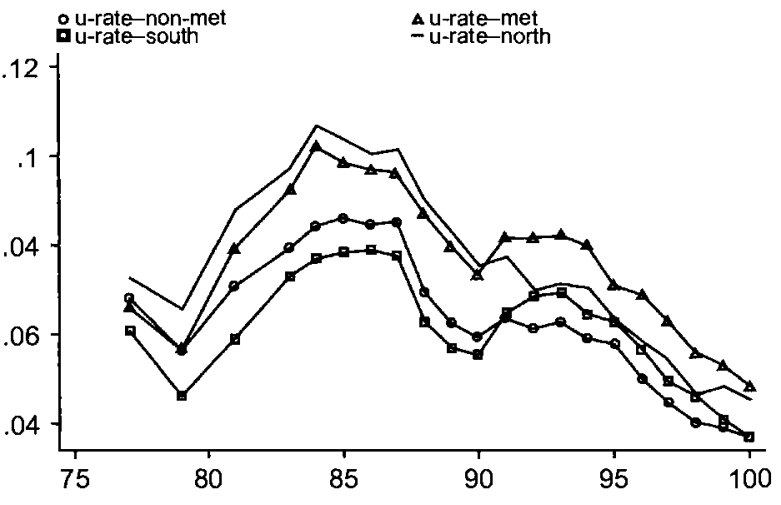

Fig. 9.2 The North-South divide and the met-non-met gap: $A$, male employment-population ratios; $B$, female employmentpopulation ratios; $C$, male unemployment rates; $D$, female unemployment rates 
We might also be interested in regional differences in wages. Comparison of the extent and evolution of regional wage inequality is complicated by the fact that it is obviously important to consider differences in real living standards, yet there are no official regional price indices for the United Kingdom. The main (and possibly the only) source of difference in regional prices is differences in housing costs. Duranton and Monastiriotis (2000) show that, although the aggregate figures appear to show an increase in regional inequality, this becomes a decline once one controls for differences in worker characteristics across regions and differences in regional living standards (see also Cameron and Muellbauer, 2000, for a discussion of the problems associated with the use of U.K. regional wage statistics).

There are a number of reasons why there might be more regional variation in employment and unemployment for the less educated. First, it may be that the shocks that affect regional labor markets are more substantial for the less educated. Second, it may be that the responsiveness to shocks is greater for the less educated (Hoynes, 1999, has presented some evidence for this in the United States). Third, it may be that regional migration acts as a "shock absorber" for regional shocks. It is difficult to distinguish between these hypotheses, although the fact that there is much more persistence in regional unemployment rates for the less educated suggests that migration might be the place to look for an explanation. This is the subject of the next section.

\section{2 “On yer bike": Lack of Work and Residential Mobility}

One way to escape any economic disadvantage associated with location is to move to a better area. In the 1980s the then Conservative minister for employment, Norman Tebbitt, observed that his father had not sat around on his backside in the Great Depression moaning about the lack of jobs: He had gotten on his bike and had looked for work. He is not the only person to have had similar thoughts. Over the years economists have worried about the lack of willingness of the British to move location to find work.

It is interesting to know whether overall residential and regional mobility rates have changed in the past twenty years. Figure 9.3 presents a time series on residential mobility rates over the past twenty years using Labour Force Survey (LFS) data. Residential mobility rates have varied between 10 and 13 percent, reaching a peak in the housing market frenzy of the late 1980s and then a trough in the subsequent crash (when house prices fell substantially). Figure 9.4 shows the evolution of regional mobility over the same period. The fraction of working-age individuals who have moved regions has only varied between 2 and 3 percent per annum in the last twenty-five years. The fraction coming from outside the United Kingdom has been very constant at about 0.7 percent, and the only variation has 


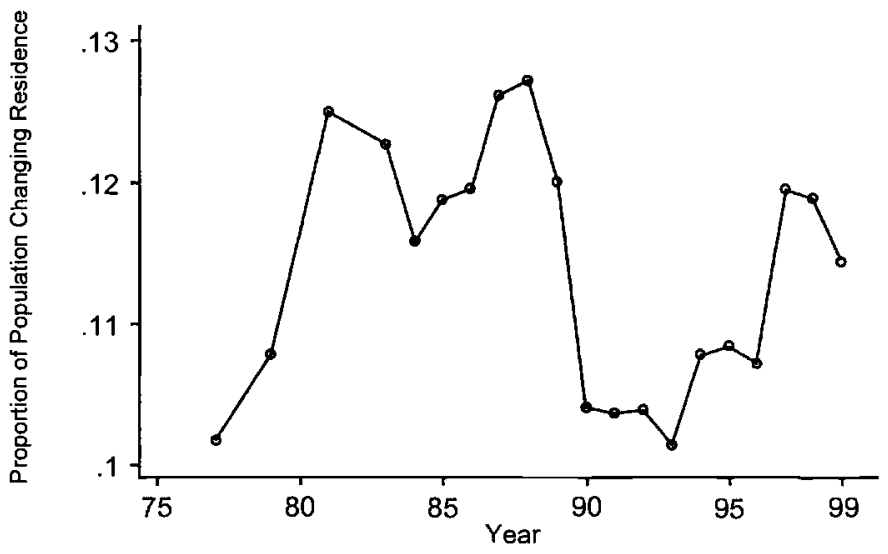

Fig. 9.3 Residential mobility in the United Kingdom, 1977-1999

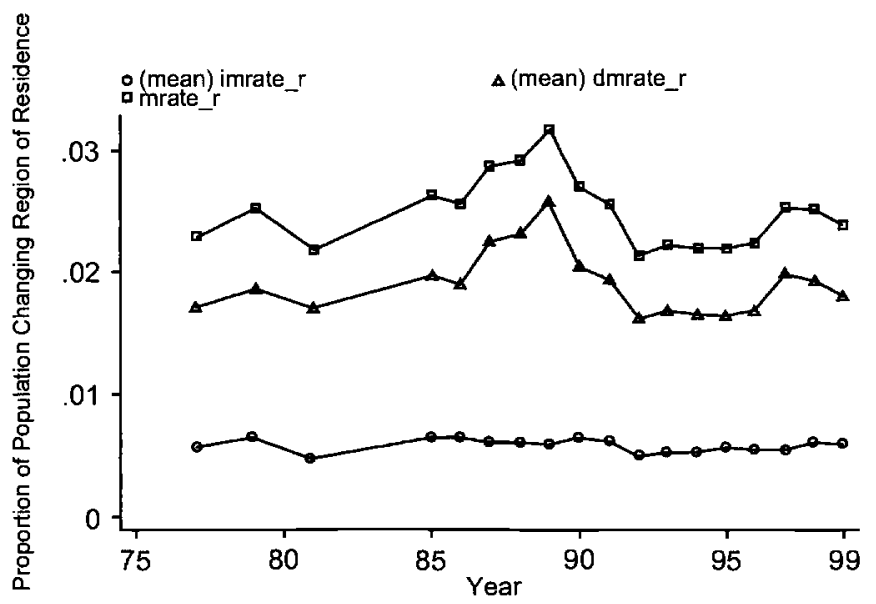

Fig. 9.4 Regional mobility in the United Kingdom: LFS data

Notes: The top line is the fraction of the population aged eighteen-sixty who have moved regions in the past year. The bottom line is the percentage who were outside the United Kingdom a year ago, and the middle line is the fraction who have moved regions within the United Kingdom.

been in regional mobility within the United Kingdom. As for residential mobility, there was a peak in the late 1980 s and then a very marked decline, since which time there has only been a weak recovery. Figure 9.5 presents data on internal migration rates (for those of all ages) from a different data source: the National Health Service Central Register (NHSCR), which is based on people's changing doctors. Two series are presented with an over- 


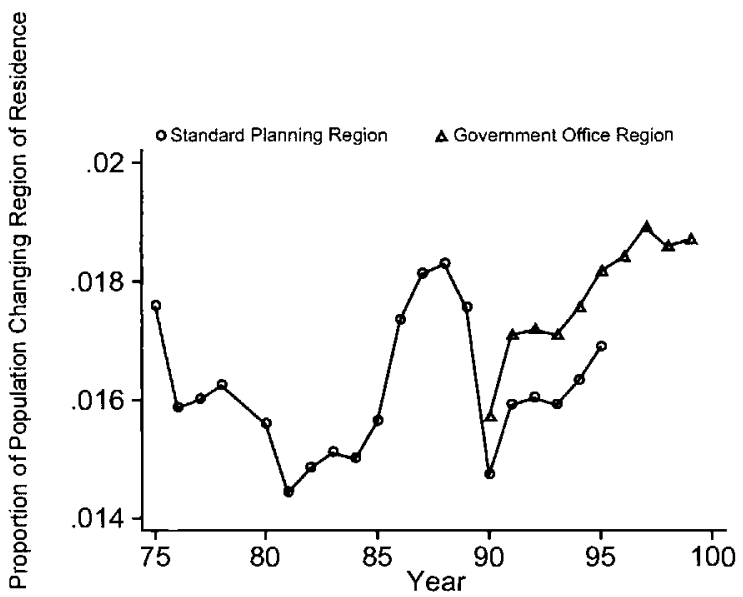

Fig. 9.5 Regional mobility in Britain: NHSCR data

Notes: This data comes from the NHSCR and is based on individuals changing doctors. It applies to all individuals.

lap, the first based on the old standard planning regions and the second based on the new government office regions. ${ }^{5}$ Internal migration appears higher on the new regional definition and seems to now be at levels last seen in the late 1980s. Neither the LFS nor the NHSCR seems to support the second part of the claim by Hughes and McCormick $(2000,16)$ that there is "a striking increase in overall migration in the mid to late 1990 s to rates in excess of those seen during any time in the last quarter century," ${ }^{\circ}$ but it does seem to be the case that regional migration is currently at levels similar to those seen at similar cyclical peaks in the past twenty-five years.

The U.K. mobility rates do not seem to be out of line with those found in other European countries. Table 9.2 uses data from the 1996-1997 wave of the European Community Household Panel (ECHPS) to calculate that around 8 percent of U.K. households moved in the year preceding the survey, which is in the middle of the range of mobility rates for the countries in the table. However, these numbers are considerably below those found in the "New World" countries (see Greenwood, 1997, table 1).

We saw earlier that there is much less regional variation in labor market outcomes for the more educated. Figure 9.6 shows that there is more regional mobility among the more educated with the regional mobility rate

5. The difference between the two is that Cumbria has been moved from the North to the Northwest region, and Bedfordshire, Essex, and Hertfordshire from the Southeast to the Eastern region. The latter change is by far the most substantive.

6. They use LFS data for the 1980s, but data from the Survey of English Housing for the $1990 \mathrm{~s}$. It is possible that the measures from the two data sets are not comparable. 


\begin{tabular}{lc}
\hline Country & Moved in Last Year (\%) \\
\hline Austria & 2.8 \\
Belgium & 6.9 \\
Denmark & 11.4 \\
Finland & 13.3 \\
France & 8.7 \\
Greece & 3.7 \\
Ireland & 4.5 \\
Italy & 3.9 \\
The Netherlands & 8.1 \\
Portugal & 3.4 \\
Spain & 4.3 \\
United Kingdom & 8.4 \\
\hline
\end{tabular}

Note: Calculated from the 1996-1997 wave of the ECHPS.

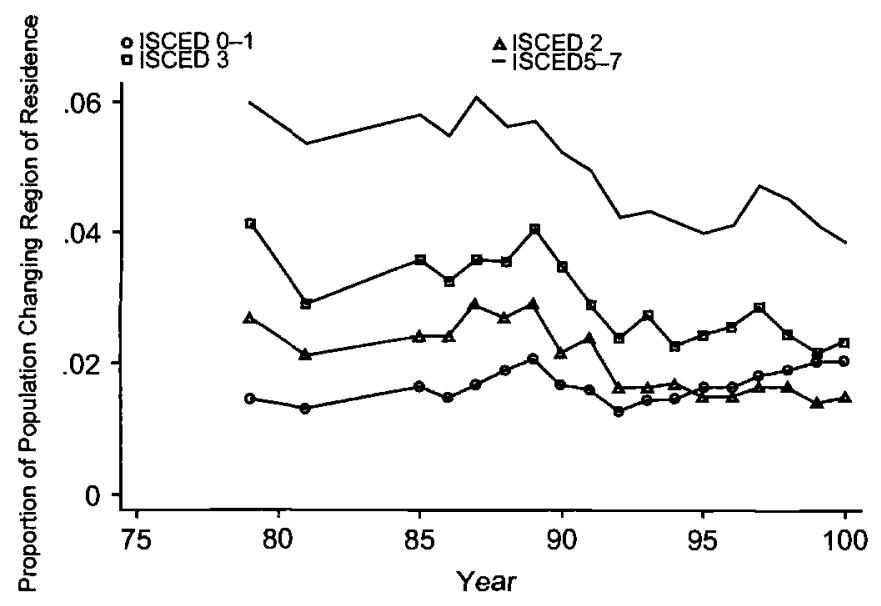

Fig. 9.6 Regional mobility in the United Kingdom, by level of education Note: This data comes from the LFS.

for graduates currently being more than twice the level of that for those without any educational qualifications. But, interestingly, the gap appears to be narrowing: In 1979 the regional mobility rate for graduates was four times that of nongraduates.

Migration does not inevitably act to reduce differentials in unemployment: For it to have this effect it needs to be predominantly from highunemployment regions to low-unemployment regions. A crude way of considering the extent to which migrants do tend to move in this direction is presented in figure 9.7 , which presents the average regional male employ- 


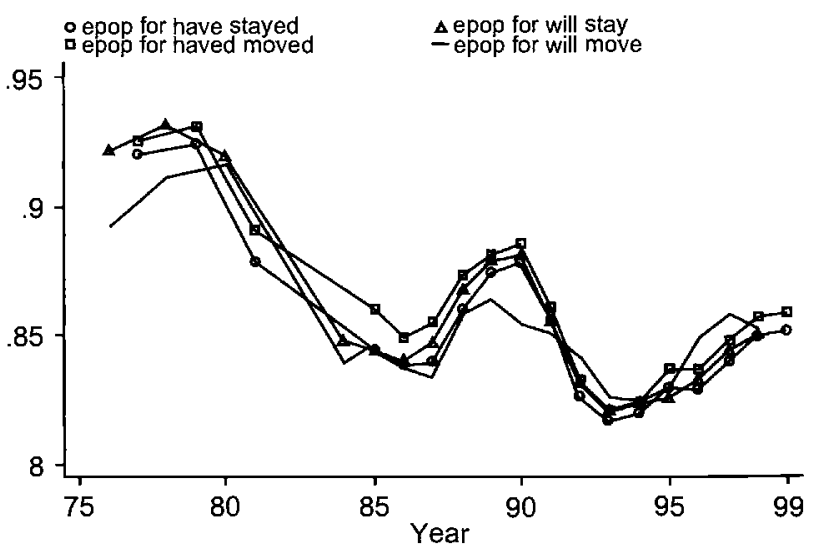

Fig. 9.7 Regional male employment-population ratios for movers and stayers

Notes: The employment-population ratio for those who will stay in their region is the employment-population ratio in the current region for those who do not move in the following year. The employment-population ratio for those who will move in their region is the employment-population ratio in the current region for those who do move in the following year (i.e., it is the employment-population ratio in the source region). The employment-population ratio for those who have stayed in their region is the employment-population ratio in the current region for those who have not moved in the past year. The employment-population ratio for those who have moved regions is the employment-population ratio in the current region for those who have moved in the past year (i.e., it is the employment-population ratio in the destination region).

ment-population ratios for those who have stayed in the same region in the past year, for those who have moved, for those who will stay in the coming year, and for those who will move. If those in high-unemployment regions are more likely to move we would expect to see a higher employmentpopulation ratio for stayers compared to those who will move. And, if movers tend to go to areas of lower unemployment, we would expect to see a higher employment-population ratio for those who have moved compared to those who have stayed. The lines are very close, although there is some tendency for the movers to be in high-employment regions, particularly in the early 1980s recovery. This indicates that migration is only weakly related to unemployment differentials.

A somewhat clearer way of presenting the same information is in figure 9.8 where we compare the change in the regional employment-population ratios for those who stay in the same region and for those who move. If the movers are motivated by improved labor market conditions then we would expect the change in the employment-population ratio to be consistently above that for the stayers. On average, the gap is positive though small, a fact that, combined with the very small fraction of regional movers, suggests that regional migration does little to offset regional differences in labor market performance. There is also a marked tendency for the gap to be 


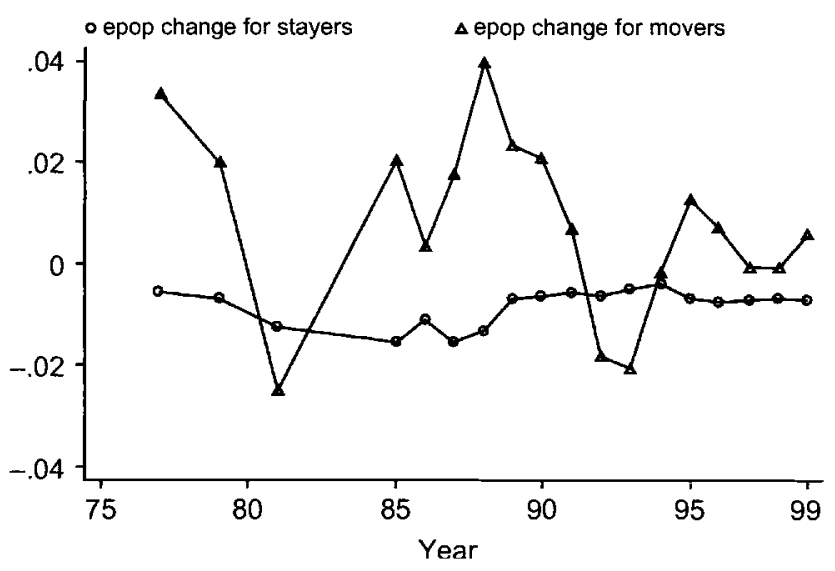

Fig. 9.8 Change in regional male employment-population ratios for movers and stayers

Notes: The employment-population change for stayers is the year-on-year change in the regional employment-population ratio for those who stay in their region. The employmentpopulation change for movers is the year-on-year change in the regional employmentpopulation ratio for those who move regions.

positive when the labor market is doing well (the late 1970s, the late 1980s, and the late 1990s). In recessions the gap is small, even negative. It seems to be easier to move regions for economic reasons when the economy is booming than when it is in recession.

Figure 9.9 examines whether there is any difference in this pattern for different education groups. It plots the difference in the change in the employment-population ratio for movers and stayers by education. There seems to be a tendency for the more educated movers to have bigger "gains," on average, than the less educated, but the gains for the less educated seem more cyclical. It is striking that through much of the 1990s less-educated regional movers actually seem to be moving into low-employment regions.

It is natural to see the difference in regional mobility rates by education as the main reason for why the graduate labor market is more integrated than that for less-educated workers. And an understanding of this difference might help us to think about how mobility for less-educated workers might be improved. There are a number of hypotheses:

1. The incentives for migration are highest for better-educated workers.

2. A major factor in determining choice of college among British students often seems to be the desire to escape from the parental home. This act of breaking away from the region in which one was brought up may make mobility easier later in life.

3. Recruitment for graduate jobs is often done at the national level with advertisements in the national press and magazines, whereas vacan- 


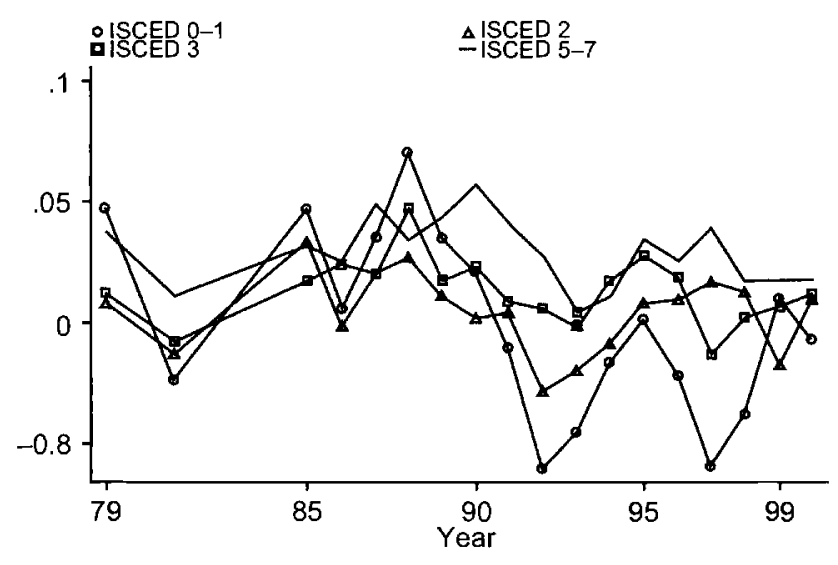

Fig. 9.9 Differences in the change in regional male employment-population ratios for movers and stayers, by education

cies in low-level jobs are typically placed in local job centers or the local press. This makes it hard to search for low-skilled jobs in regions where one is not living.

4. A higher fraction of less-educated individuals live in social housing, which has often been argued to discourage mobility (see Hughes and McCormick 1981).

\subsection{The Economic Returns to Migration}

It may be that the economic incentives for migration are higher for better-educated workers. Consider the following simple model for determining the economic incentives for migration. In any region, $r$, there will be a probability of employment, $e_{r}$; a real wage if in employment $W_{r}$; and a level of real benefits, $B_{r}$, if unemployed. Expected utility in region $r, Y_{r}$, will then be given by

$$
Y_{r}=U\left(B_{r}\right)+e_{r}\left[U\left(W_{r}\right)-U\left(B_{r}\right)\right],
$$

if the utility function is given by $U(\cdot)$. Given that housing benefit largely insulates the unemployed from variations in the cost of housing, it is probably not a bad approximation to assume that $B_{r}$ does not vary across regions. Suppose we compare expected income in a potential region for migration with the home region (denoted by subscript $h$ ). We will have

$$
Y_{r}-Y_{h}=e_{r}\left[U\left(W_{r}\right)-U\left(W_{h}\right)\right]+\left(e_{r}-e_{h}\right) U\left[\left(W_{h}\right)-U(B)\right] .
$$

The economic incentives for migration will be higher, the higher the righthand side of equation (2). There may be a return to migration because of 
regional differences in real wages or regional differences in employment rates. The importance of the latter depends on the gap between living standards when in and out of employment. The earlier discussion on regional wage inequalities suggested that, to a first approximation, there are only small differences in real regional wages so that it is the difference in employment prospects that provides the main motivation for migration in the United Kingdom. As we saw in figure 9.1, there are larger regional differences in employment rates among the less-skilled that, other things being equal, should mean that the incentive to migrate is higher for these workers. However, it is also true that the return to being in work $[U(W)-U(B)]$ is smaller for this group, and this tends to reduce the incentives to migrate.

Evaluating which effect is larger is a bit tricky as assumptions about the different employment prospects and about the marginal utility of income in different regions are needed. But let us make some back-of-the-envelope calculations using the average employment rate in different regions and assuming utility is given by the log of income. The gap in employment rates between the best and worst regions is about 0.10 for graduates and 0.25 for those without qualifications. The earnings gap between these two groups is approximately $50 \log$ points. Using these numbers we will have that the return to migration for graduates is larger if

$$
0.10 x[0.5-\ln (R)]>-0.25 x \ln (R) \Rightarrow \ln (R)>-0.33 \Rightarrow R>0.72,
$$

where $R$ is the replacement ratio $(B / W)$ for those without qualifications. The replacement ratio in the United Kingdom is normally thought to be below this level although it is sensitive to the treatment of housing costs. But this suggests that it is certainly not obvious that the economic returns to migration are highest for the more educated, and it is quite possible that the opposite is true. An explanation for the low rates of regional migration for the less educated should probably focus on the costs of migration rather than the returns.

\subsection{Graduates and the Move Away from Home}

In the United Kingdom, young people of ten move away from home when they go to college. For students studying full-time for a first degree in 1998-1999, just over half of the students were studying in a region that is not in the region where their parents live. The regional mobility among students going to college far exceeds levels of regional mobility found for any other group in the U.K. economy at any other point in the life cycle. One hypothesis for why the graduate labor market is more integrated is that the break with the parental region at age eighteen makes it easier to move regions later in life: If the individual has broken the ties of family and friends once, it may be easier to do it again.

There is some evidence for this if we look at the region in which under- 
The Regional Destination of the First Jobs of Graduates

\begin{tabular}{|c|c|c|c|c|c|c|c|}
\hline \multirow[b]{2}{*}{ Parental } & \multirow[b]{2}{*}{$\begin{array}{l}\text { Percent } \\
\text { of } \\
\text { Students }\end{array}$} & \multirow[b]{2}{*}{$\begin{array}{l}\text { Percent Who } \\
\text { Study in } \\
\text { Parental Region }\end{array}$} & \multicolumn{2}{|c|}{$\begin{array}{l}\text { Study in Parental } \\
\text { Region }(\%)\end{array}$} & \multicolumn{3}{|c|}{$\begin{array}{c}\text { Do Not Study in Parental } \\
\text { Region }(\%)\end{array}$} \\
\hline & & & $\begin{array}{l}\text { First Job in } \\
\text { Parental } \\
\text { Region }\end{array}$ & $\begin{array}{c}\text { First Job } \\
\text { in Other } \\
\text { Region }\end{array}$ & $\begin{array}{c}\text { First Job in } \\
\text { Parental } \\
\text { Region }\end{array}$ & $\begin{array}{c}\text { First Job } \\
\text { in Study } \\
\text { Region }\end{array}$ & $\begin{array}{c}\text { First Job } \\
\text { in Other } \\
\text { Region }\end{array}$ \\
\hline East Anglia & 3.3 & 23 & 75 & 25 & 43 & 25 & 32 \\
\hline East Midlands & 7.2 & 26 & 72 & 28 & 39 & 27 & 34 \\
\hline Greater London & 11.7 & 52 & 87 & 13 & 66 & 18 & 16 \\
\hline North & 4.9 & 44 & 80 & 20 & 37 & 31 & 32 \\
\hline Northwest & 10.7 & 45 & 85 & 15 & 47 & 25 & 28 \\
\hline Northern Ireland & 4.0 & 99 & 88 & 12 & 36 & 35 & 29 \\
\hline Scotland & 8.9 & 80 & 87 & 13 & 35 & 28 & 37 \\
\hline Southeast & 20.0 & 50 & 74 & 26 & 46 & 25 & 29 \\
\hline Southwest & 8.2 & 42 & 77 & 23 & 39 & 31 & 30 \\
\hline Wales & 5.3 & 49 & 84 & 16 & 34 & 31 & 35 \\
\hline West Midlands & 8.2 & 36 & 84 & 16 & 45 & 25 & 30 \\
\hline \multicolumn{8}{|l|}{ Yorkshire and } \\
\hline Humberside & 7.8 & 29 & 78 & 22 & 41 & 28 & 31 \\
\hline
\end{tabular}

Note: These data come from HEFCE and relate to full-time first-degree students registered in 1998 1999 .

graduates get their first job. Table 9.3 presents some statistics by parental region on the percentage of students who move away to college, on the percentage of first jobs in the parental region for those who studied in the parental region, and on the percentage of first jobs in the parental region and region of study for those who went away to college. ${ }^{7}$ A number of points are worth noting. First, a much higher fraction of students who study in the parental region also get their first job in that region. Second, for those students who moved regions to go to college, the parental region still has some pulling power when it comes to getting jobs and so does the region in which they studied. But a higher fraction take their third job in a region other than the one in which they studied or lived as a child than do those who studied in the parental region. In the absence of further information, the interpretation of these statistics is problematic as it is likely that it is those children with an outward-looking mentality who go away to college and are then prepared to consider jobs in a wider range of regions. But they are consistent with the idea that breaking away from the parental home to go to college also makes it easier to move regions later in life. Figures from the British Household Panel Study (BHPS) suggest that this is not a recent phenomenon: In the adult population as a whole, only 12 per-

7. We are grateful to Abigail $\mathrm{McKnight}$ for providing us with these figures from the Higher Education Funding Council for England (HEFCE). 
cent of graduates live in the local authority where they were born, compared to 44 percent among the rest of the population. It is perhaps worth noting that more college students are likely to live at home in the future as they now have to bear a higher fraction of their costs of tuition, and this may act to reduce regional mobility among graduates in the future.

\subsection{Unemployment, Housing Tenure, and Residential Mobility}

We have already seen evidence that, on average, the better educated are more likely to move regions. But figure 9.6 does not control for any other relevant factors, and we might want to know whether this remains the case even once one controls for other factors. Two of the most relevant factors are probably labor market status and housing tenure.

There is considerable research on the factors associated with residential and regional mobility in the United Kingdom (e.g., Hughes and McCormick 1981, 1985, 1987; Pissarides and Wadsworth 1989; Jackman and Savouri 1992; Henley 1998; Boheim and Taylor 2000), much of which focuses on questions like "are the unemployed more likely to move?" The research on the relationship between residence and economic fortunes is plagued by an inability to separate causality. For example, it is almost certainly true that residence is likely to change when there are changes in circumstances: changes in household structure (leaving the parental home, marriage, divorce, birth of a child, etc.) or changes in labor market outcomes (getting a job, losing a job, getting a promotion, etc.). We might expect that both "good" and "bad" shocks are related to changes in residence. On the other hand there is the feeling that residence (primarily location) determines economic opportunity and hence that changes in residence affect changes in economic opportunity.

Existing research is very poor at disentangling the direction of causality. To do it properly, researchers would seem to need some good instruments, but those are hard to find. In the absence of good instruments, we are going to describe the correlations in the data and offer an interpretation.

We use two data sets to investigate the determinants of mobility: the BHPS and the LFS. Boheim and Taylor (2000) have recently presented an analysis of residential mobility using the BHPS, and we will follow on from their research. Unlike them, we split the sample into those who are in couples for whom household mobility is likely to be most important (see Mincer 1978) and those who are not in couples for whom individual characteristics are likely to be most important.

In table 9.4 and table 9.5 we report basic residential and regional mobility equations for the BHPS for individuals and couples, respectively. ${ }^{8}$

8. The BHPS also asks questions about mobility across local authority district, but these are not shown here as the results were very similar. 


\begin{tabular}{|c|c|c|c|c|c|}
\hline \multirow{2}{*}{$\begin{array}{c}\text { Residential } \\
\text { (entire sample) }\end{array}$} & \multirow{2}{*}{\multicolumn{2}{|c|}{$\begin{array}{c}\text { Regional } \\
\text { (entire sample) }\end{array}$}} & \multicolumn{3}{|c|}{ Regional } \\
\hline & & & New & Social & \\
\hline (2) & (3) & (4) & (5) & (6) & (7) \\
\hline
\end{tabular}

Housing Characteristics (base category: owner occupier with mortgage)

\begin{tabular}{|c|c|c|c|c|c|c|c|}
\hline Own house outright & $\begin{array}{c}.004 \\
(.012)\end{array}$ & $\begin{array}{l}.004 \\
(.012)\end{array}$ & $\begin{array}{l}-.004 \\
(.004)\end{array}$ & $\begin{array}{l}-.004 \\
(.004)\end{array}$ & $\begin{array}{l}.021 \\
(.023)\end{array}$ & & $\begin{array}{l}-.009 \\
(.006)\end{array}$ \\
\hline Social housing tenant & $\begin{array}{c}.030 \\
(.012)\end{array}$ & $\begin{array}{c}.028 \\
(.012)\end{array}$ & $\begin{array}{c}-.013 \\
(.004)\end{array}$ & $\begin{array}{c}-.013 \\
(.003)\end{array}$ & $\begin{array}{c}-.012 \\
(.016)\end{array}$ & & $\begin{array}{c}-.030 \\
(0.005)\end{array}$ \\
\hline Private unfurnished tenant & $\begin{array}{l}.152 \\
(.021)\end{array}$ & $\begin{array}{c}.149 \\
(.022)\end{array}$ & $\begin{array}{c}.007 \\
(.006)\end{array}$ & $\begin{array}{c}.505 \\
(.006)\end{array}$ & $\begin{array}{l}-.020 \\
(.019)\end{array}$ & & $\begin{array}{l}-.0115 \\
(.008)\end{array}$ \\
\hline Private furnished tenant & $\begin{array}{c}.297 \\
(.021)\end{array}$ & $\begin{array}{c}.296 \\
(.021)\end{array}$ & $\begin{array}{c}.028 \\
(.007)\end{array}$ & $\begin{array}{c}.024 \\
(.007)\end{array}$ & $\begin{array}{c}.048 \\
(.024)\end{array}$ & & $\begin{array}{r}-.0097 \\
(.008)\end{array}$ \\
\hline $\begin{array}{l}\text { Responsible for housing } \\
\text { Rent subsidy }\end{array}$ & $\begin{array}{l}-.066 \\
(.016)\end{array}$ & $\begin{array}{c}-.064 \\
(.016)\end{array}$ & $\begin{array}{c}.004 \\
(.005)\end{array}$ & $\begin{array}{l}-.503 \\
(.004)\end{array}$ & $\begin{array}{c}.018 \\
(.019)\end{array}$ & $\begin{array}{c}.003 \\
(.008) \\
.0025 \\
(.0030)\end{array}$ & \\
\hline \multicolumn{8}{|c|}{ Labor Force Status (base category: employed) } \\
\hline Unemployed & $\begin{array}{c}.019 \\
(.014)\end{array}$ & $\begin{array}{c}.012 \\
(.014)\end{array}$ & $\begin{array}{c}.012 \\
(.006)\end{array}$ & $\begin{array}{c}.007 \\
(.006)\end{array}$ & $\begin{array}{l}-.013 \\
(.014)\end{array}$ & $\begin{array}{r}.0096 \\
(.011)\end{array}$ & $\begin{array}{c}.0328 \\
(.0132)\end{array}$ \\
\hline Retired & $\begin{array}{l}.067 \\
(.057)\end{array}$ & $\begin{array}{c}.073 \\
(.059)\end{array}$ & $\begin{array}{c}.038 \\
(.037)\end{array}$ & $\begin{array}{c}.046 \\
(.040)\end{array}$ & & & \\
\hline Family care & $\begin{array}{l}.020 \\
(.017)\end{array}$ & $\begin{array}{c}.026 \\
(.018)\end{array}$ & $\begin{array}{c}.013 \\
(.008)\end{array}$ & $\begin{array}{c}.018 \\
(.009)\end{array}$ & $\begin{array}{c}.015 \\
(.033)\end{array}$ & $\begin{array}{c}.005 \\
(.009)\end{array}$ & $\begin{array}{c}.036 \\
(.023)\end{array}$ \\
\hline Full-time student & $\begin{array}{l}.051 \\
(.017)\end{array}$ & $\begin{array}{c}.055 \\
(.015)\end{array}$ & $\begin{array}{c}.043 \\
(.008)\end{array}$ & $\begin{array}{c}.048 \\
(.009)\end{array}$ & $\begin{array}{c}.030 \\
(.018)\end{array}$ & $\begin{array}{c}.021 \\
(.020)\end{array}$ & $\begin{array}{c}.074 \\
(.013)\end{array}$ \\
\hline Long-term sick & $\begin{array}{l}.016 \\
(.025)\end{array}$ & $\begin{array}{c}.022 \\
(.026)\end{array}$ & $\begin{array}{c}.009 \\
(.014)\end{array}$ & $\begin{array}{c}.014 \\
(.015)\end{array}$ & $\begin{array}{c}.039 \\
(.078)\end{array}$ & & $\begin{array}{l}.065 \\
(.050)\end{array}$ \\
\hline New job & & $\begin{array}{c}.051 \\
(.011)\end{array}$ & & $\begin{array}{c}.031 \\
(.005)\end{array}$ & & $\begin{array}{c}.0128 \\
(.0086)\end{array}$ & $\begin{array}{c}.011 \\
(.007)\end{array}$ \\
\hline Lost job & & $\begin{array}{c}.061 \\
(.020)\end{array}$ & & $\begin{array}{c}.057 \\
(.013)\end{array}$ & & $\begin{array}{c}.0269 \\
(.0168)\end{array}$ & $\begin{array}{c}.054 \\
(.019)\end{array}$ \\
\hline \multicolumn{8}{|c|}{ Education (base category: ISCED 3) } \\
\hline ISCED 0-1 & $\begin{array}{c}-.0245 \\
(.0136)\end{array}$ & $\begin{array}{c}-.0227 \\
(.0135)\end{array}$ & $\begin{array}{c}-.0148 \\
(.0042)\end{array}$ & $\begin{array}{l}\cdots .0133 \\
(.0038)\end{array}$ & $\begin{array}{c}-.0390 \\
(.0173)\end{array}$ & $\begin{array}{l}-.0098 \\
(.0042)\end{array}$ & $\begin{array}{c}-.0230 \\
(.0065)\end{array}$ \\
\hline ISCED 2 & $\begin{array}{l}-.0254 \\
(.0093)\end{array}$ & $\begin{array}{c}-.0239 \\
(.0093)\end{array}$ & $\begin{array}{l}-.0125 \\
(.0032)\end{array}$ & $\begin{array}{l}-.0110 \\
(.0030)\end{array}$ & $\begin{array}{l}-.0322 \\
(.0125)\end{array}$ & $\begin{array}{l}-.0060 \\
(.0043)\end{array}$ & $\begin{array}{l}-.0217 \\
(.0053)\end{array}$ \\
\hline ISCED 5-7 & $\begin{array}{c}.0139 \\
(.0127)\end{array}$ & $\begin{array}{c}.0129 \\
(.0126)\end{array}$ & $\begin{array}{c}.0114 \\
(.0050)\end{array}$ & $\begin{array}{c}.0103 \\
(.0047)\end{array}$ & $\begin{array}{c}.0124 \\
(.0176)\end{array}$ & $\begin{array}{c}-.0043 \\
(.0031)\end{array}$ & $\begin{array}{c}.0128 \\
(.0099)\end{array}$ \\
\hline No. of observations & 11,063 & 11,063 & 11,063 & 11,063 & 1,783 & 981 & 4,669 \\
\hline Pseudo- $R^{2}$ & .150 & 0.153 & .0169 & 0.190 & 0.186 & 0.268 & 0.133 \\
\hline $\begin{array}{l}\text { Mean of the dependent } \\
\text { variable }\end{array}$ & .192 & .192 & .046 & .046 & .098 & 0.030 & 0.053 \\
\hline
\end{tabular}

Notes: Coefficients are marginal effects. Standard errors (in parentheses) are robust and corrected for clustering on the individual. Other controls are age, education, nonwhite, child of household head, lone parent, region, and wave. 


\begin{tabular}{|c|c|c|c|c|c|}
\hline \multirow{2}{*}{\multicolumn{2}{|c|}{$\begin{array}{c}\text { Residential } \\
\text { (entire sample) }\end{array}$}} & \multirow{2}{*}{\multicolumn{2}{|c|}{$\begin{array}{c}\text { Regional } \\
\text { (entire sample) }\end{array}$}} & \multicolumn{2}{|c|}{ Regional } \\
\hline & & & & \multirow{2}{*}{$\begin{array}{c}\text { New Jobs }>0 \\
\text { (5) }\end{array}$} & \multirow{2}{*}{$\begin{array}{l}\text { Social Housing } \\
\text { (6) }\end{array}$} \\
\hline (1) & (2) & (3) & (4) & & \\
\hline
\end{tabular}

Housing Characteristics (base category: owner occupier with mortgage)

\begin{tabular}{|c|c|c|c|c|c|c|}
\hline Own house outright & $\begin{array}{l}.010 \\
(.008)\end{array}$ & $\begin{array}{c}.009 \\
(.008)\end{array}$ & $\begin{array}{l}-.001 \\
(.002)\end{array}$ & $\begin{array}{l}-.002 \\
(.002)\end{array}$ & $\begin{array}{c}-0.000 \\
(0.010)\end{array}$ & \\
\hline Social housing tenant & $\begin{array}{c}.038 \\
(.008)\end{array}$ & $\begin{array}{c}.033 \\
(.008)\end{array}$ & $\begin{array}{l}-.000 \\
(.003)\end{array}$ & $\begin{array}{l}-.001 \\
(.002)\end{array}$ & $\begin{array}{c}.002 \\
(.010)\end{array}$ & \\
\hline Private unfurnished tenant & $\begin{array}{l}.146 \\
(.018)\end{array}$ & $\begin{array}{l}.141 \\
(.017)\end{array}$ & $\begin{array}{c}.016 \\
(.506)\end{array}$ & $\begin{array}{c}.012 \\
(.005)\end{array}$ & $\begin{array}{l}.002 \\
.010)\end{array}$ & \\
\hline Private furnished tenant & $\begin{array}{l}.328 \\
(.032)\end{array}$ & $\begin{array}{r}.323 \\
(0.31)\end{array}$ & $\begin{array}{c}.032 \\
(.011)\end{array}$ & $\begin{array}{c}.026 \\
(.010)\end{array}$ & $\begin{array}{c}.063 \\
(.027)\end{array}$ & \\
\hline Rent subsidy & & & & & & $\begin{array}{c}-.0057 \\
(.0068)\end{array}$ \\
\hline \multicolumn{7}{|c|}{ Labour Force Status (base category: employed) } \\
\hline Workless & $\begin{array}{c}.018 \\
(.009)\end{array}$ & $\begin{array}{c}.024 \\
(.009)\end{array}$ & $\begin{array}{c}.001 \\
(.003)\end{array}$ & $\begin{array}{l}.003 \\
(.003)\end{array}$ & $\begin{array}{l}-.001 \\
(.008)\end{array}$ & $\begin{array}{c}-.0047 \\
(.0048)\end{array}$ \\
\hline Dual & $\begin{array}{l}.001 \\
(.005)\end{array}$ & $\begin{array}{c}.001 \\
(.004)\end{array}$ & $\begin{array}{l}-.000 \\
(.002)\end{array}$ & $\begin{array}{l}-.000 \\
(.001)\end{array}$ & $\begin{array}{l}.008 \\
(.005)\end{array}$ & $\begin{array}{c}-.0006 \\
(.0052)\end{array}$ \\
\hline No. of new jobs & & $\begin{array}{c}.018 \\
(.004)\end{array}$ & & $\begin{array}{l}.007 \\
(.001)\end{array}$ & & $\begin{array}{l}.0101 \\
(.0078)\end{array}$ \\
\hline No. of lost jobs & & $\begin{array}{c}.032 \\
(.005)\end{array}$ & & $\begin{array}{c}.012 \\
(.001)\end{array}$ & & $\begin{array}{l}.0098 \\
(.0082)\end{array}$ \\
\hline \multicolumn{7}{|c|}{ Education (base category: ISCED 3) } \\
\hline ISCED 0-1 & $\begin{array}{l}-.0189 \\
(.0058)\end{array}$ & $\begin{array}{c}-.0191 \\
(.0056)\end{array}$ & $\begin{array}{l}-.0064 \\
(.0018)\end{array}$ & $\begin{array}{l}-.0057 \\
(.0014)\end{array}$ & $\begin{array}{l}-.0065 \\
(.0060)\end{array}$ & $\begin{array}{l}-.0030 \\
(.0050)\end{array}$ \\
\hline ISCED 2 & $\begin{array}{l}-.0088 \\
(.0047)\end{array}$ & $\begin{array}{l}-.0085 \\
(.0046)\end{array}$ & $\begin{array}{l}-.0046 \\
(.0017)\end{array}$ & $\begin{array}{l}-.0040 \\
(.0014)\end{array}$ & $\begin{array}{l}-.0063 \\
(.0053)\end{array}$ & $\begin{array}{l}-.0281 \\
(.0192)\end{array}$ \\
\hline ISCED 5-7 & $\begin{array}{c}.0039 \\
(.0057)\end{array}$ & $\begin{array}{l}.0031 \\
(.0056)\end{array}$ & $\begin{array}{c}.0064 \\
(.0026)\end{array}$ & $\begin{array}{c}.0047 \\
(.0022)\end{array}$ & $\begin{array}{c}.0131 \\
(.0077)\end{array}$ & $\begin{array}{l}-.0046 \\
(.0043)\end{array}$ \\
\hline No. of observations & 14,090 & 14,090 & 14,090 & 14,090 & 2,972 & 377 \\
\hline Pseudo- $R^{2}$ & 0.126 & 0.132 & 0.102 & 0.151 & 0.128 & 0.229 \\
\hline $\begin{array}{l}\text { Mean of the dependent } \\
\text { variable }\end{array}$ & .076 & .076 & .013 & .013 & .026 & .032 \\
\hline
\end{tabular}

Note: See table 9.4.

Tables 9.6 and 9.7 report similar equations for the LFS where we can look at changes over longer periods and have larger sample sizes but with the disadvantage that we have a narrower range of covariates (notably, we do not have initial housing tenure except in a few years). We report only the coefficients on the variables in which we are interested, namely initial labor market status, housing tenure, and education: The other controls are listed. Younger workers are more likely to move, and ethnic minorities and households with school-age children are less likely to move. 


\begin{tabular}{|c|c|c|c|c|c|c|c|c|c|}
\hline & & & & & \multicolumn{5}{|c|}{ Regional } \\
\hline & \multicolumn{4}{|c|}{ Residential (entire sample) } & \multirow{2}{*}{$\begin{array}{l}\text { ISCED } 0-1 \\
\text { (5) }\end{array}$} & \multirow{2}{*}{$\begin{array}{l}\text { ISCED } 2 \\
(6)\end{array}$} & \multirow{2}{*}{$\begin{array}{l}\text { ISCED } 3 \\
(7)\end{array}$} & \multirow{2}{*}{$\begin{array}{l}\text { ISCED } 4 \\
(8)\end{array}$} & \multirow{2}{*}{$\begin{array}{c}\text { New Job }=1 \\
(9)\end{array}$} \\
\hline & (1) & (2) & (3) & (4) & & & & & \\
\hline \multicolumn{10}{|c|}{ Labor Force Status (base category: employed) } \\
\hline \multirow[t]{2}{*}{ Unemployed } & .0326 & .0302 & .0061 & .0035 & .0037 & .0013 & .0063 & .0039 & -.0158 \\
\hline & $(.0016)$ & $(.0016)$ & $(.0007)$ & $(.0006)$ & $(.0006)$ & $(.0009)$ & $(.0022)$ & $(.0028)$ & $(.0017)$ \\
\hline \multirow[t]{2}{*}{ Retired } & .0055 & .0132 & .0058 & .0097 & .0096 & .0017 & .0178 & .0176 & -.0289 \\
\hline & $(.0052)$ & $(.0055)$ & $(.0025)$ & $(.0028)$ & $(.0031)$ & $(.0049)$ & $(.0166)$ & $(.0110)$ & $(.0080)$ \\
\hline \multirow[t]{2}{*}{ Family care } & .0063 & .0154 & .0019 & .0056 & .0037 & .0048 & .0052 & .0078 & -.0160 \\
\hline & $(.0014)$ & $(.0015)$ & $(.0006)$ & $(.0007)$ & $(.0006)$ & $(.0013)$ & $(.0035)$ & $(.0045)$ & $(.0028)$ \\
\hline \multirow[t]{2}{*}{ Full-time student } & .0786 & .0785 & .0296 & .0262 & .0091 & .0038 & .0234 & .0595 & .0291 \\
\hline & $(.0022)$ & $(.0022)$ & $(.0011)$ & $(.0010)$ & $(.0023)$ & $(.0013)$ & $(.0018)$ & $(.0036)$ & $(.0027)$ \\
\hline \multirow[t]{2}{*}{ Other inactive } & .0485 & .0579 & .0078 & .0111 & .0066 & .0070 & .0192 & .0271 & -.0102 \\
\hline & $(.0022)$ & $(.0024)$ & $(.0010)$ & $(.0011)$ & $(.0009)$ & $(.0020)$ & $(.0052)$ & $(.0065)$ & $(.0041)$ \\
\hline \multirow[t]{2}{*}{ New job } & & .0420 & & .0228 & .0137 & .0190 & .0259 & .0633 & \\
\hline & & $(.0013)$ & & $(.0007)$ & $(.0009)$ & $(.0012)$ & $(.0016)$ & $(.0027)$ & \\
\hline \multirow[t]{2}{*}{ Lost job } & & .0855 & & .0369 & .0228 & .0283 & .0625 & .0834 & \\
\hline & & $(.0024)$ & & $(.0014)$ & $(.0016)$ & $(.0023)$ & $(.0044)$ & $(.0064)$ & \\
\hline \multicolumn{10}{|c|}{ Education (base category: ISCED 3) } \\
\hline \multirow[t]{2}{*}{ ISCED 0-1 } & -.0075 & -.0087 & -.0066 & -.0065 & & & & & -.0182 \\
\hline & $(.0011)$ & $(.0011)$ & $(.0004)$ & $(.0003)$ & & & & & $(.0019)$ \\
\hline \multirow[t]{2}{*}{ ISCED 2} & -.0094 & -.0098 & -.0043 & -.0042 & & & & & -.0118 \\
\hline & $(.0011)$ & $(.0010)$ & $(.0003)$ & $(.0003)$ & & & & & $(.0019)$ \\
\hline \multirow[t]{2}{*}{ ISCED 5-7 } & .0138 & .0129 & .0101 & .0078 & & & & & .0459 \\
\hline & $(.0013)$ & $(.0013)$ & $(.0006)$ & $(.0005)$ & & & & & $(.0033)$ \\
\hline No. of observations & 555,450 & 555,450 & 555,450 & 555,450 & 245,643 & 140,430 & 88,950 & 80,427 & 69,724 \\
\hline Pseudo- $R^{2}$ & .184 & .192 & .172 & .202 & .100 & .134 & .220 & .231 & 0.194 \\
\hline Mean of the dependent variable & .107 & .107 & .0235 & .0235 & .0109 & .0169 & .0410 & .0544 & .0664 \\
\hline
\end{tabular}

Note: Other controls are gender, age dummies, nonwhite, foreign-born, lone parent, number of kids, child of head of household, other relative of head of household, region, and year dummies. 


\begin{tabular}{|c|c|c|c|c|c|c|c|c|c|}
\hline & \multicolumn{2}{|c|}{$\begin{array}{c}\text { Residential } \\
\text { (entire sample) }\end{array}$} & \multicolumn{2}{|c|}{$\begin{array}{c}\text { Regional } \\
\text { (entire sample) }\end{array}$} & \multicolumn{5}{|c|}{ Regional } \\
\hline & (1) & (2) & (3) & (4) & $\begin{array}{l}\text { ISCED 0-1 } \\
\text { (5) }\end{array}$ & $\begin{array}{l}\text { ISCED } 2 \\
\quad(6)\end{array}$ & $\begin{array}{l}\text { ISCED } 3 \\
\text { (7) }\end{array}$ & $\begin{array}{c}\text { ISCED } 4 \\
(8)\end{array}$ & $\begin{array}{c}\text { New Jobs }>0 \\
(9)\end{array}$ \\
\hline \multirow[t]{2}{*}{ Workless } & .027 & .033 & .0022 & .0031 & .0032 & .0026 & .0030 & .0037 & .0052 \\
\hline & $(.002)$ & $(.002)$ & $(.0009)$ & $(.0009)$ & $(.0010)$ & $(.0016)$ & $(.0026)$ & $(.0031)$ & $(.0031)$ \\
\hline Dual & -.015 & -.013 & -.0067 & -.0054 & -.0019 & -.0045 & -.0067 & -.0120 & .0028 \\
\hline No. of new jobs & & $(.001)$ & & $(.0003)$ & $(.0004)$ & $(.0004)$ & $(.0008)$ & $(.0009)$ & \\
\hline \multirow[t]{2}{*}{ No. of lost jobs } & & .045 & & .0148 & .0102 & .0128 & .0146 & .0297 & \\
\hline & & $(.001)$ & & $(.0004)$ & $(.0006)$ & $(.0006)$ & $(.0013)$ & $(.0014)$ & \\
\hline \multicolumn{10}{|c|}{ Education (base category: ISCED 3) } \\
\hline \multirow{2}{*}{ ISCED 0-1 } & .0018 & .0009 & -.0051 & -.0048 & & & & & -.0115 \\
\hline & $(.0014)$ & $(.0014)$ & $(.0005)$ & $(.0004)$ & & & & $(.0019)$ & \\
\hline No. of observations & 294,938 & 294,938 & 294,938 & 294,938 & 95,750 & 77,754 & 57,541 & 63,893 & 58,728 \\
\hline Pseudo- $R^{2}$ & .097 & .107 & .065 & .110 & .095 & .097 & .083 & .136 & .057 \\
\hline Mean of the dependent variable & .101 & .101 & .0179 & .0179 & .0123 & .0142 & .0195 & .0291 & .0391 \\
\hline
\end{tabular}

Notes: Coefficients are marginal effects. Other controls are age and age squared of man and woman, nonwhite, foreign-born, number and age of dependent children, child of household head, region, and year dummies. 


\subsection{Unemployment and Residential Mobility}

One of the main methods of adjustment to regional shocks envisaged by economists is that workers without work in depressed regions are motivated to move to look for work in other regions where the employment possibilities are better. It might be necessary to physically move to the new location to look for work there, or it might be possible to search for work in one part of the country from another part and only move when work is obtained. In this section, we will argue that speculative moves to find work are very rare in the United Kingdom and that the most common pattern of mobility is that first a job is obtained and then a residential move follows.

For individuals the unemployed are more likely to move both regions and residence, although the coefficient in the residential mobility equation is not significantly different from zero for the BHPS. This is in line with other studies: As McCormick $(1997,587)$ summarizes it, "all UK studies which examine the effect of individual unemployment ... find this has a strong positive effect on out-migration." The implication often drawn is that those who lack work are spurred by this to change location in search of better economic opportunities. But these regressions do not justify such a conclusion as they do not identify the reason for the move. It is worth noting that other labor force states are also associated with effects on moving that are often as large as the impact of unemployment: for example, retirement. Yet such moves are unlikely to be motivated by the search for work. Being a full-time student is associated with a very high marginal effect on mobility, presumably because of the impact that being a college student has on leaving the parental home and moving regions.

One can also see very clearly the link between changes in employment status and residential moves by including in a residential mobility equation a dummy variable for whether an individual has a new job or has lost a job. ${ }^{9}$ For an individual who was initially unemployed the variable "new job" takes the value 1 if they now have a job, while for those who were initially employed it takes the value 1 if they have changed jobs. Unsurprisingly, both these variables are incredibly significant when included in residential mobility equations. The importance of the "lost job" variable also indicates that residential mobility may be associated with bad as well as good shocks to the individual's labor market fortunes. The inclusion of the "got job" and "lost job" variables reduces the marginal effect of unemployment for individuals in both the BHPS and the LFS, although it raises the marginal effect of the workless household variable for couples. However, if we

9. Boheim and Taylor (2000) do examine the relationship between job changes and residential moves but use a bivariate probit model to do so. It is not clear that this is the best way of modeling the interactions, as it is best suited to the situation where unobserved characteristics are correlated with both outcomes rather than a case where the two outcomes themselves are linked. 
restrict the sample to those who have gotten a job, the unemployed (or workless) are less likely to have moved regions than those in work (column [5] of tables 9.4 and 9.5 and column [9] of tables 9.6 and 9.7).

Of the 2.4 percent of those unemployed a year ago who move, 47 percent are now in employment, 41 percent are unemployed, and 12 percent are inactive. This compares to 31 percent, 55 percent, and 14 percent for those who do not move. This could be interpreted as showing that regional mobility is very successful in getting the unemployed jobs. But one can interpret the data in two ways. Either the unemployed move house first and then find a job, or they find a job first and then seek to move house if the commute is too inconvenient given their present location. The policy implications of the two views are rather different, as it may not be policies that make residential mobility easier that are needed but policies to make it easier for workers in one area to find work elsewhere.

Ideally, one would like data on when jobs were obtained to compare with the date of residential mobility, but we typically only have data on when jobs were started that is more likely to postdate residential mobility. There are a number of ways in which we can try to get some idea of the likely sequence of events.

Since 1996 the LFS asks specific information about the month of a residential move and the month in which the job started. If the unemployed move regions and then find work, we would expect to see a time lag between the change in residence and getting a job. In fact, the average time lag is 0.9 months. If the unemployed engage in speculative moves to look for work, this implies implausibly short durations of unemployment in the destination region. And the time lag is actually shorter than for those who have had a job-to-job move (so have no intervening period of unemployment) and moved regions (their time lag is one month). It is possible that the unemployed first move to a new region, stay with friends or family, and only move residence when they got a job. But average residential tenure among regional movers is identical for the previously unemployed and jobto-job movers (5.8 months). So this does not seem very persuasive. All of this evidence is very circumstantial, but it does suggest a picture in which it is rare for the unemployed to move regions without first having found themselves a job.

This evidence does not answer the question about the motivation for unemployed regional movers who do not make the transition into employment. The BHPS does contain information on the motivation for residential moves. In particular it asks whether the reason for a move was jobrelated, and, if so, the respondent is asked to elaborate. Table 9.8 tabulates the responses. Only 12 percent of residential moves are reported to be motivated by employment reasons, although this rises to 31 percent among regional movers. Employment-related reasons are less often given by those who are currently not in employment. And even where employment- 


\begin{tabular}{lcccc}
\hline & $\begin{array}{c}\text { Residential } \\
\text { Movers }\end{array}$ & $\begin{array}{c}\text { Regional } \\
\text { Movers }\end{array}$ & $\begin{array}{c}\text { Nonemployed } \\
\text { Movers }\end{array}$ & $\begin{array}{c}\text { Nonemploycd } \\
\text { Regional } \\
\text { Movers }\end{array}$ \\
\hline Moved for employment reasons & 12.3 & 31.0 & 10.4 & 24.6 \\
Employer relocated & $(5,847)$ & $(1,194)$ & $(2,317)$ & $(552)$ \\
New job, same employer & 4.4 & 5.1 & 0 & 0 \\
New job, ncw employer & $(675)$ & $(352)$ & $(205)$ & $(120)$ \\
& 11.4 & 13.6 & 3.4 & 2.5 \\
Closer to same job & $(675)$ & $(352)$ & $(205)$ & $(120)$ \\
& 36.0 & 42.0 & 41.5 & 43.3 \\
Start/relocate own business & $(675)$ & $(352)$ & $(205)$ & $(120)$ \\
Salary increase-new home & 17.2 & 9.4 & 5.5 & 2.5 \\
& $(675)$ & $(352)$ & $(205)$ & $(120)$ \\
To seek work & 6.8 & 5.9 & 2.9 & 1.6 \\
& $(675)$ & $(352)$ & $(205)$ & $(120)$ \\
Other & 3.5 & 0.3 & 0 & 0 \\
& $(675)$ & $(352)$ & $(205)$ & $(120)$ \\
& 8.7 & 11.6 & 20.5 & 25.0 \\
& $(675)$ & $(352)$ & $(205)$ & $(120)$ \\
& 19.2 & 16.8 & 31.5 & 29.4 \\
& $(675)$ & $(352)$ & $(205)$ & $(120)$ \\
\hline
\end{tabular}

Notes: Sample sizes are reported in parentheses. The second and subsequent rows give the percentages of those who said they had moved for employment reasons who gave more specific answers when requested to elaborate on this.

related reasons are given, a very small fraction report that they were motivated by seeking work: Reasons that imply that the job came first and mobility subsequently are much more important. The bottom line would be that of the 2 percent of the nonemployed who move regions, 25 percent are motivated by job-related reasons, and, of those, 25 percent are motivated by the desire to seek work. It is hard to escape the conclusion that speculative regional mobility by the unemployed is very rare.

This evidence is not perfect, but it does suggest that it is important to obtain a job before moving and that it is very unlikely for the unemployed to move location without having a job. ${ }^{10}$ This is not that surprising. It is not very easy to change location if there is no source of income. Banks and building societies are likely to be reluctant to give mortgages to those without work, even if one already has one. And private landlords are also likely to regard these people as bad risks as prospective tenants. This problem does not seem to be unique to the United Kingdom: The ethnographic account of Ehrenreich (2001) about life as a low-wage worker in the United

10. It is quite likely that the unemployed who move regions initially stay with friends and family in the destination region. The finding that immigrants in the United States tend to go where immigrants from their home country already are is consistent with this. It suggests that high levels of past migration may make current migration easier. 
States is full of the difficulties caused by finding accommodation when moving to a new city.

This also suggests that one of the problems faced by the less educated in moving regions is the difficulty they have in searching for work in another region as a result of the lack of regional integration of the vacancy system. Tables 9.6 and 9.7 estimate separate mobility equations by education for LFS individuals and couples. The marginal effects of the "got job" and "lost job" variables are much larger for the more educated.

But why are vacancies for less-skilled jobs predominantly advertised at local level? It could be that there is no point in advertising in Scotland for an unskilled job in the Southeast because none of the unskilled in Scotland will be interested in taking that job. However, our earlier analysis suggests that the economic returns to job mobility may be higher for the less skilled. Perhaps more plausible is the argument that, when unemployment is high, there is a ready supply of less-skilled workers in all localities. There is no point in advertising for workers in distant regions if there is an excess supply locally. But the consequence of this policy for each individual employer is to trap some workers in high-unemployment regions and to shut off the route by which less-skilled workers can migrate from high- to lowunemployment regions.

If this hypothesis is correct, we might expect to see more attempts by employers to recruit less-skilled workers from further afield as labor markets tighten. This can then explain why the migration from high- to lowunemployment regions seems greater in booms than recessions as we saw in figure 9.8. Perhaps the most celebrated and extreme example of this was the process of recruitment of workers in the West Indies by London Transport when faced with a recruitment crisis in the 1950s and 1960s. Booms increase the supply of vacancies overall and the fraction of vacancies for jobs in other regions, so booms grease the wheels of migration.

One other possible explanation for the lack of speculative moves by the unemployed is that the structure of the housing market makes this difficult. There is some evidence for such frustrated residential mobility. Using data from the BHPS, those in social and private rented housing are more likely to want to move and particularly likely to continue to want to move, even if they have just done so. Let us move on to consider the role of the housing market in more detail.

\subsection{Housing Tenure and Residential Mobility}

The housing market plays a very important part in determining where people live and hence has a potentially large impact on both regional and neighborhood inequalities. And the housing market has also seen some of the most dramatic changes in the United Kingdom in the last twenty years. In 1979 , something like 57 percent of the working-age population were 
owner-occupiers, 32 percent were in social housing (provided by local councils or nonprofit housing associations), and 10 percent were private rented tenants. By 1999,75 percent were owner-occupiers, 16 percent were in social housing, and 9 percent were private rented tenants. The main reason for this transformation was the "right-to-buy" policy introduced by Margaret Thatcher in the 1980 Housing Act that gave council tenants subsidies to buy their houses. To date, 1.7 million tenants have taken advantage of this. At the same time, local councils were prevented from using the proceeds to build new houses: Whereas councils had completed 145,000 new homes in 1977 ( 46 percent of the total), by 1995 this had fallen to 2,000 (1 percent of the total).

Those who remained in social housing had their rents raised in the early 1980 s, although they remain well below market rents ( $30-40$ percent below, according to most estimates). The impact of this was mitigated in part by the system of welfare support for tenants (called Housing Benefit after 1982), which paid 100 percent of rents subject to a means-test and a number of restrictions on the maximum allowable rent. In theory the U.K. system of housing benefit should make regional mobility easier as it may pay all the housing costs of those who are unemployed. However, the system is notorious for the inefficiency of its administration, and a recent survey (United Kingdom, Department of the Environment, Transport, and Regions 1999) found that only 1 percent of landlords had a positive preference for tenants on housing benefit, while 18 percent had an aversion to tenants on housing benefit. The two most common problems with tenants on housing benefit cited were problems with administration of housing benefit and rent arrears (which are also likely to be related to administrative problems).

For private tenants in receipt of housing benefit, the deregulation of rents meant, in theory, that any rent could be charged by the landlord and paid for in full by the state. ${ }^{11}$ Expenditure on housing benefit for private tenants rose dramatically, and steps were introduced in the mid-1990s to limit the payment of housing benefit to individuals, first to the undertwenty-five-year-olds (who are restricted to an amount that is paid for a room in a shared house) and then to others. Reform of housing benefit remains on the agenda, and a number of options for reform are discussed in the April 2000 green paper "Quality and Choice: A Decent Home for All" (United Kingdom, Department of the Environment, Transport, and Regions 2000).

For owner-occupiers, the main government policy has been the steady

11. One still sees the statement "no DSS [Department for Social Security]" in many ads for rental properties, even ones that are quite expensive, for example, $£ 1000$ per month. What is surprising is that anyone on welfare benefits could even consider living in such accommodation. 
restriction and eventual withdrawal of the mortgage interest relief at source (MIRAS) scheme by which interest payments were tax-deductible. For those owner-occupiers out of work, mortgage interest payments could be covered by welfare benefits. In the mid-1990s these were restricted in the amount and a nine-month waiting period was introduced before owneroccupiers would have their mortgage covered by a welfare payment. Perhaps more important than changing government policy was financial market liberalization in the 1980s, which made it easier to get a mortgage.

Let us consider the impact of housing tenure on residential mobility. Relative to the base category of owner-occupiers with a mortgage, those in social housing are more likely to move residence but less likely to move regions, and those in private rented housing are much more likely to move both residence and regions, with those in furnished rental properties the most mobile by a large factor.

There are a number of possible reasons for why those in social housing might be less likely to move regions. One is that such housing remains heavily subsidized, and it is very difficult to move into equivalent subsidized housing in another local authority because the properties are generally allocated using a procedure that gives a very high weight to residence in the local authority. One can see this in the data-only 14 percent of new lettings in social housing are movers from another region, compared to 37 percent of new private-sector lettings.

There are a number of ways to test this hypothesis. One is to try to estimate the size of the subsidy (which differs across local authorities) and then see whether this is related to mobility. Column (6) of tables 9.4 and 9.5 does this without much success.

Another hypothesis is that it is simply the characteristics of those in social housing that make the difference. One way of looking at this is to consider those who are not responsible for the housing costs in their residence (mostly children of the head of household). For this group we still see the same pattern of housing tenure effects (see column [7] of table 9.4) as in the full sample, suggesting that housing costs may have little to do with the housing tenure effects.

\subsection{Neighborhood Inequalities: Is Britain Ghettoizing?}

The previous discussion has all been about interregional dispersion. But the regions are very aggregated and hide enormous differences within regions. In this section we examine the distribution of employment and unemployment at the most disaggregated level available for the United Kingdom: enumeration districts (which average about 375 residents). Data at this level of disaggregation are only available from the decennial censuses, so we only have 1981 and 1991 to work with. Although this is rather dated, 
this does cover a period of considerable change and turbulence in the U.K. labor market in which overall wage inequality rose substantially (see Gosling and Lemieux 2001). Unfortunately, the U.K. census contains no income information, so this discussion will focus on employment-related outcomes only.

The male unemployment rate was 11.7 percent in 1981 and 11.3 percent in 1991. The absence of any dramatic change in the level of unemployment makes it easier to consider changes in the distribution of unemployment across neighborhoods, although it should be borne in mind that the regional distribution of unemployment was rather different in the two years, with unemployment being relatively higher in the south in 1991 .

Panel A of figure 9.10 shows the male unemployment rates by neighbourhood from the lowest to the highest in 1981 and 1991 (this is just the cumulative density function for the unemployment rate). As can be seen, the two lines are extremely similar, indicating that there is rather little change: The unemployment rate at the 10 th percentile is about 4.5 percent, while it is 20 percent at the 90 th percentile. As the lines are so similar, panel $B$ of figure 9.10 presents the change in the unemployment rate at each percentile. The magnitudes of the changes are very small, although there seems to be some tendency for the best and worst areas to worsen, while those in the middle do slightly better.

Given the rise in male inactivity rates in this period, it is also worth considering changes in male employment-population ratios. Panels C and D of figure 9.10 do a similar exercise as the previous one for nonemployment rates. Unfortunately, it does not seem possible to compute the nonemployment rate for working-age men in 1981, so this is based on all men aged sixteen or over. ${ }^{12}$ There is a rise in the male nonemployment rate over this period (see panel C of figure 9.10), and this is largest in absolute terms in the worst enumeration districts (see panel D of figure 9.10). However, in proportional terms there is no very dramatic change in the nonemployment rate at different percentiles.

It is also worth considering women as their employment trends were rather different over this period. Panels $\mathrm{E}-\mathrm{H}$ of figure 9.10 show similar pictures for the unemployment and nonemployment rates for women. Both their unemployment and nonemployment rates were lower in 1991 than 1981. The fall in unemployment rates is larger in the worst areas, but the fall in nonemployment rates was less.

The analysis so far has made no attempt to match enumeration districts in 1981 and 1991 so that it cannot answer questions about the types of areas that had big changes in employment. Because of boundary changes, it is not always possible to match enumeration districts across the two censuses,

12. For 199l the correlation across enumeration districts of the employment-population ratio for all men and for working-age men is 0.88 . 
A

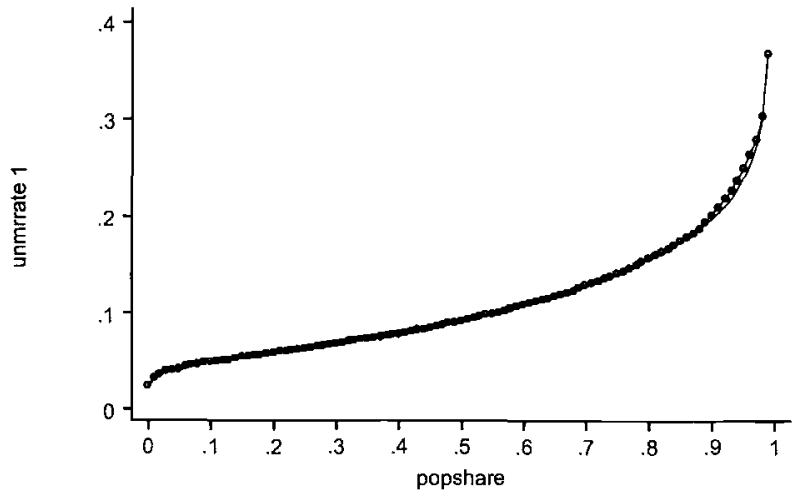

B

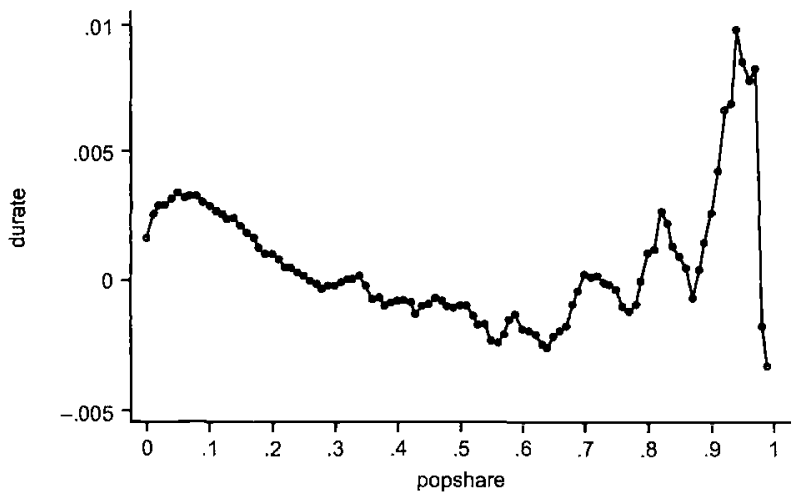

C

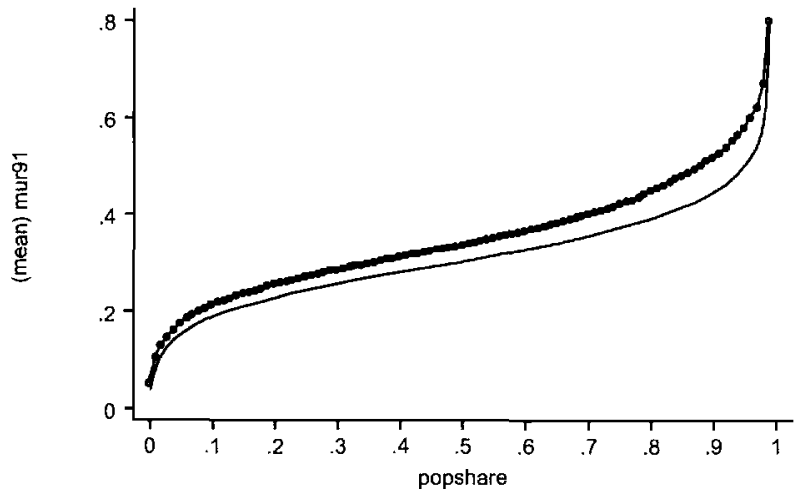

Fig. 9.10 $A$, The distribution of male unemployment rates, 1981 and 1991; $B$, the change in male unemployment rates at different percentiles, 1981-1991; $C$, the distribution of male nonemployment rates, 1981 and $1991 ; D$, the change in male nonemployment rates at different percentiles, 1981-1991; $E$, the distribution of female unemployment rates, 1981 and $1991 ; F$, the change in female unemployment rates at different percentiles, 1981-1991; $G$, the distribution of female nonemployment rates, 1981 and $1991 ; H$, the change in female nonemployment rates at different percentiles, 1981-1991 
D

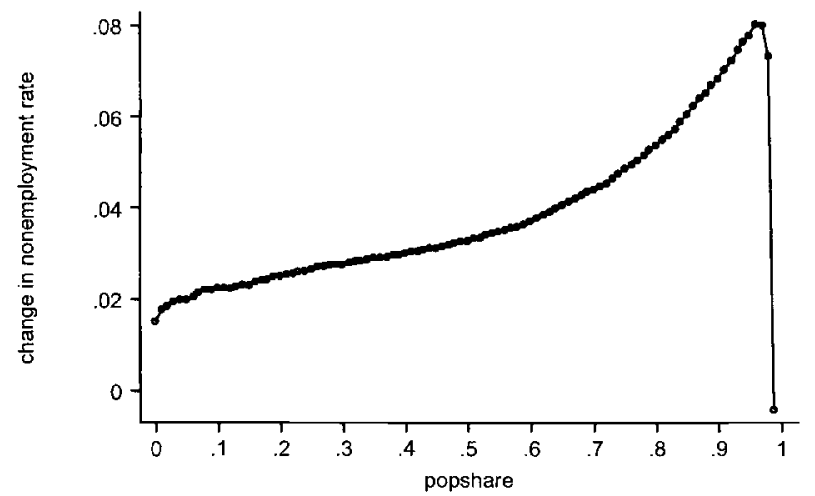

$E$

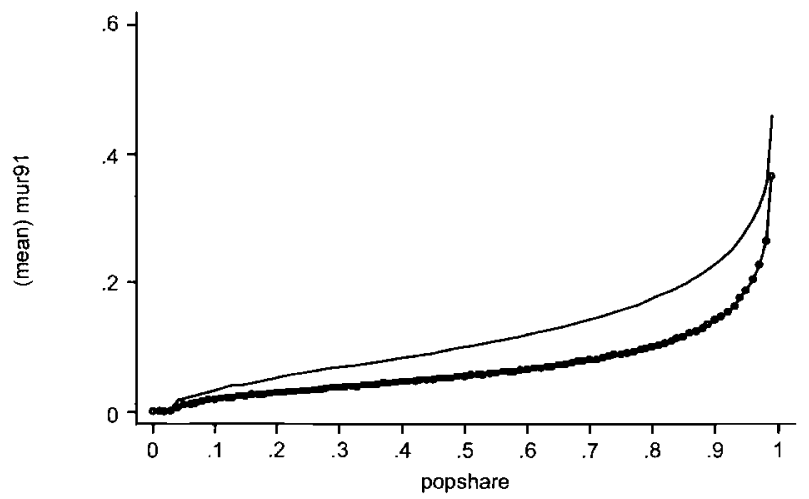

$\mathrm{F}$

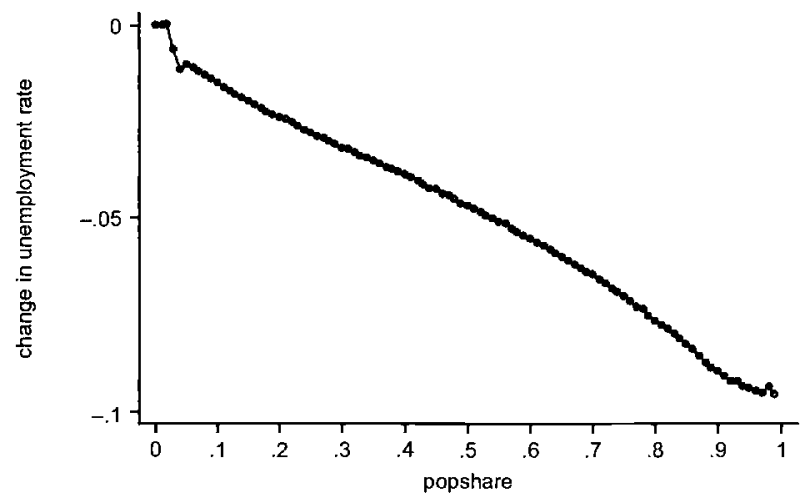

Fig. 9.10 (cont.) $A$, The distribution of male unemployment rates, 1981 and 1991; $B$, the change in male unemployment rates at different percentiles, 1981-1991; $C$, the distribution of male nonemployment rates, 1981 and $1991 ; D$, the change in male nonemployment rates at different percentiles, 1981-1991; $E$, the distribution of female unemployment rates, 1981 and $1991 ; F$, the change in female unemployment rates at different percentiles, 1981 -1991; $G$, the distribution of female nonemployment rates, 1981 and $1991 ; H$, the change in female nonemployment rates at different percentiles, 1981-1991 
G

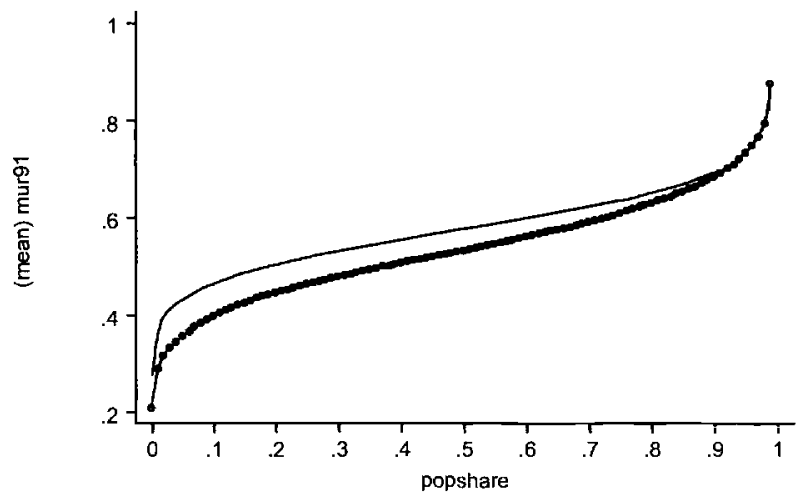

H

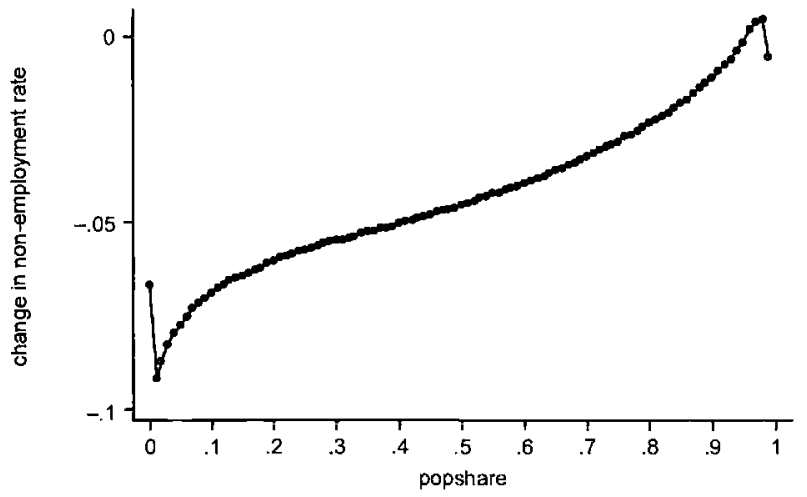

Fig. 9.10 (cont.) $G$, the distribution of female nonemployment rates, 1981 and 1991; $H$, the change in female nonemployment rates at different percentiles, 1981-1991

but this can be done for about 7,400 of them. Table 9.9 investigates the determinants of the change in unemployment and nonemployment rates on a variety of initial characteristics about its inhabitants in 1981. The variables included are limited by data availability but include the tenure distribution of the housing stock and the social class of heads of households. As can be seen, once geographical controls (here, parliamentary constituencies) are introduced, there is no evidence that those areas with more households from the lower social classes in 1981 fared less well over the ten-year period 1981-1991.

Figure 9.11 looks at whether there has been any increased polarization in area crime rates. This is based on data from the British Crime Surveys (BCS) of 1984 and 1996, which contain data on crime victimization at the household level in the year preceding the survey. The figure plots 1983 to 1995 changes in area crime rates at different percentiles for around 600 areas in the 1984 survey and 800 areas in the 1996 survey. It shows some 


\begin{tabular}{|c|c|c|c|c|c|c|c|c|}
\hline \multirow{2}{*}{$\begin{array}{l}1981 \text { Area } \\
\text { Characteristics } \\
\text { Proportion in: }\end{array}$} & \multicolumn{4}{|c|}{ Males } & \multicolumn{4}{|c|}{ Females } \\
\hline & \multicolumn{2}{|c|}{$\begin{array}{c}\text { Unemployment } \\
\text { Rate }\end{array}$} & \multicolumn{2}{|c|}{$\begin{array}{c}\text { Nonemployment } \\
\text { Rate }\end{array}$} & \multicolumn{2}{|c|}{$\begin{array}{c}\text { Unemployment } \\
\text { Ratc }\end{array}$} & \multicolumn{2}{|c|}{$\begin{array}{c}\text { Nonemployment } \\
\text { Rate }\end{array}$} \\
\hline LA & $\begin{array}{c}.036 \\
(.002)\end{array}$ & $\begin{array}{c}.014 \\
(.002)\end{array}$ & $\begin{array}{c}.063 \\
(.003)\end{array}$ & $\begin{array}{c}.055 \\
(.003)\end{array}$ & $\begin{array}{c}.017 \\
(.002)\end{array}$ & $\begin{array}{l}-.016 \\
(.003)\end{array}$ & $\begin{array}{c}.100 \\
(.003)\end{array}$ & $\begin{array}{c}.099 \\
(.003)\end{array}$ \\
\hline Private rented & $\begin{array}{l}.087 \\
(.006)\end{array}$ & $\begin{array}{l}-.006 \\
(.006)\end{array}$ & $\begin{array}{l}-.048 \\
(.007)\end{array}$ & $\begin{array}{l}-.110 \\
(.008)\end{array}$ & $\begin{array}{l}.090 \\
(.006)\end{array}$ & $\begin{array}{c}.002 \\
(.007)\end{array}$ & $\begin{array}{l}.034 \\
(.007)\end{array}$ & $\begin{array}{l}.019 \\
(.008)\end{array}$ \\
\hline HA & $\begin{array}{l}.084 \\
(.011)\end{array}$ & $\begin{array}{l}.035 \\
(.009)\end{array}$ & $\begin{array}{l}.102 \\
(.013)\end{array}$ & $\begin{array}{c}.064 \\
(.012)\end{array}$ & $\begin{array}{l}.059 \\
(.011)\end{array}$ & $\begin{array}{l}-.009 \\
(.010)\end{array}$ & $\begin{array}{l}.120 \\
(.013)\end{array}$ & $\begin{array}{l}.079 \\
(.013)\end{array}$ \\
\hline Job-related rent & $\begin{array}{l}-.028 \\
(.010)\end{array}$ & $\begin{array}{c}.024 \\
(.009)\end{array}$ & $\begin{array}{l}-.005 \\
(.012)\end{array}$ & $\begin{array}{c}.058 \\
(.012)\end{array}$ & $\begin{array}{l}-.142 \\
(.011)\end{array}$ & $\begin{array}{l}-.083 \\
(.010)\end{array}$ & $\begin{array}{l}-.260 \\
(.013)\end{array}$ & $\begin{array}{l}-.115 \\
(.013)\end{array}$ \\
\hline Nonpermanent & $\begin{array}{l}-.043 \\
(.020)\end{array}$ & $\begin{array}{l}-.047 \\
(.015)\end{array}$ & $\begin{array}{l}-.008 \\
(.023)\end{array}$ & $\begin{array}{c}.022 \\
(.020)\end{array}$ & $\begin{array}{l}-.056 \\
(.022)\end{array}$ & $\begin{array}{l}-.044 \\
(.018)\end{array}$ & $\begin{array}{l}-.039 \\
(.023)\end{array}$ & $\begin{array}{l}.036 \\
(.022)\end{array}$ \\
\hline Social class I & $\begin{array}{c}.049 \\
(.014)\end{array}$ & $\begin{array}{l}-.001 \\
(.011)\end{array}$ & $\begin{array}{c}.063 \\
(.016)\end{array}$ & $\begin{array}{c}.079 \\
(.015)\end{array}$ & $\begin{array}{l}.139 \\
(.015)\end{array}$ & $\begin{array}{l}.046 \\
(.013)\end{array}$ & $\begin{array}{c}.048 \\
(.016)\end{array}$ & $\begin{array}{c}.053 \\
(.016)\end{array}$ \\
\hline Social class II & $\begin{array}{c}.038 \\
(.011)\end{array}$ & $\begin{array}{l}-.006 \\
(.009)\end{array}$ & $\begin{array}{c}.025 \\
(.013)\end{array}$ & $\begin{array}{c}.047 \\
(.012)\end{array}$ & $\begin{array}{c}.123 \\
(.012)\end{array}$ & $\begin{array}{c}.045 \\
(.010)\end{array}$ & $\begin{array}{l}-.051 \\
(.013)\end{array}$ & $\begin{array}{l}-.014 \\
(.013)\end{array}$ \\
\hline Social class III & $\begin{array}{l}.047 \\
(.011)\end{array}$ & $\begin{array}{l}. .004 \\
(.009)\end{array}$ & $\begin{array}{l}.044 \\
(.014)\end{array}$ & $\begin{array}{c}.038 \\
(.013)\end{array}$ & $\begin{array}{l}.083 \\
(.012)\end{array}$ & $\begin{array}{c}.024 \\
(.011)\end{array}$ & $\begin{array}{l}-.070 \\
(.014)\end{array}$ & $\begin{array}{l}.005 \\
(.013)\end{array}$ \\
\hline Social class IV & $\begin{array}{l}.017 \\
(.013)\end{array}$ & $\begin{array}{l}.004 \\
(.010)\end{array}$ & $\begin{array}{l}.029 \\
(.016)\end{array}$ & $\begin{array}{l}.035 \\
(.014)\end{array}$ & $\begin{array}{l}.038 \\
(.014)\end{array}$ & $\begin{array}{c}.022 \\
(.012)\end{array}$ & $\begin{array}{l}.001 \\
(.016)\end{array}$ & $\begin{array}{l}.007 \\
(.015)\end{array}$ \\
\hline Constituency controls & No & Yes & No & Yes & No & No & No & No \\
\hline No. of observations & 7,417 & 7,417 & 7,417 & 7,417 & 7,417 & 7,417 & 7,417 & 7,417 \\
\hline$R^{2}$ & 0.06 & 0.53 & 0.14 & 0.45 & 0.10 & 0.47 & 0.34 & 0.54 \\
\hline
\end{tabular}

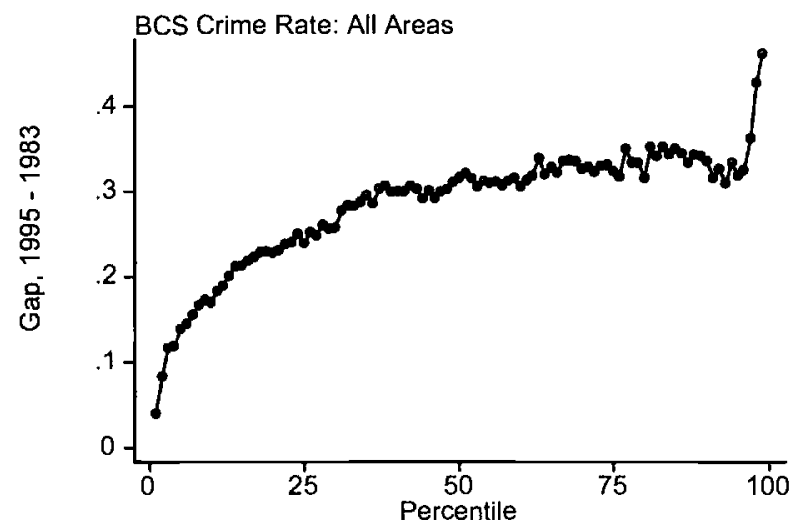

Fig. 9.11 The change in area crime rates at different percentiles, 1983-1995 Source: Calculated from the 1984 and 1996 BCSs. 
evidence of increased crime at the higher percentiles, although most of the profile after the median is fairly flat (with crime rates about 0.3 higher in 1995 as compared to 1983), except right at the top of the distribution.

This section has shown that the United Kingdom does have big inequalities between neighborhoods but that it has always had them, and there do not seem to be any very clear trends in the period 1981-1991.

\subsection{Council House Sales}

The most dramatic change in the U.K. housing market in the last twenty years has been the sale of council houses to private individuals following on from the 1980 Housing Act. Something like one-third of council houses were sold in the following ten years. The April 2000 green paper "Quality and Choice: A Decent Home for All" claimed that "right to buy sales have helped foster mixed-income communities by keeping more affluent households in the same areas" (United Kingdom, Department of the Environment, Transport, and Regions 2000, 55). But it is not immediately obvious that this is the case. If council houses had been sold at random, then mixed communities would have been likely to result. But if, as is sometimes claimed, council houses were only sold in the "nicer" areas and virtually none were sold on the worst estates, then the mixed communities would disappear, and we would end up with a situation in which neighborhoods were either all council or all owner-occupied. The best data set for looking at these effects is the census, as the bulk of council house sales were concentrated in the period 1981-1991.

Figure 9.12 plots the change in the proportion of council house tenants

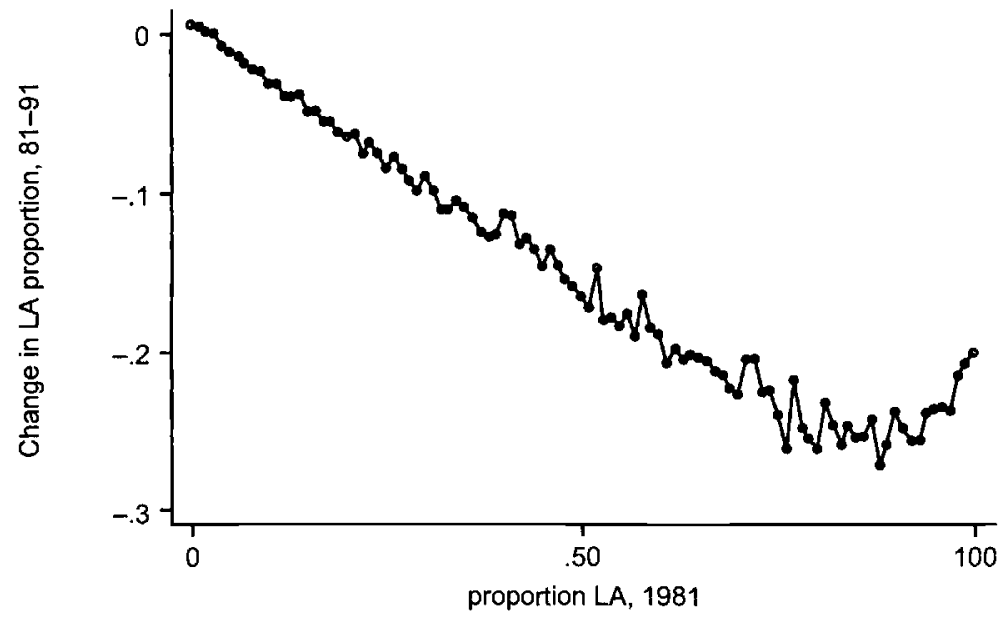

Fig. 9.12 How council house sales varied by neighborhoods, 1981-1995 
in an enumeration district against the proportion council house tenants in 1981. There is some evidence that the sales in council housing were smaller in the neighborhoods with the highest initial concentrations of council housing. But the effect is very modest, and 20 percent of council houses are still being sold in the most concentrated estates. The consequence is that, whereas in 1981, 1.1 percent of neighborhoods were 100 percent council and 8.3 percent were more than 95 percent, this had fallen to 0.2 percent and 1.2 percent, respectively, by 1991 .

However, these statistics do not tell us anything about the people living in the houses that had been council. Obviously, when a council house is first sold, there is no immediate change in the composition of the neighborhood. But some types of council tenants were more likely to buy than others, and, when these move on, it is the characteristics of the households who replace them that are of interest. Some anecdotal accounts suggest that excouncil houses have been sold to private landlords who then allow the properties to decay, leading to rapid worsening in neighborhoods (see, for example, Davies 1998).

Table 9.10 draws on data from the 1984 LFS, which had an extra supplement on housing, and on the Survey of English Housing in the 1990s. It presents marginal effects derived from probit models of council house purchased by people who were previously living in council accommodation (i.e., those council tenants who bought the property they lived in). Two specifications are reported for each data source, one which includes social class measures and one which does not. The pattern of purchase is clear in both time periods considered. It is very much the people with access to resources who were more likely to have bought their council property. For example, the probability of purchase is higher for older heads of household and is considerably lower in workless households. Furthermore, it is higher for people with from higher-social class backgrounds. ${ }^{13}$

However, this evidence cannot tell us anything about how council house sales have influenced the social composition of neighborhoods. For that, we need to know how the characteristics of those who exercised the right to buy their council house differ from those that they subsequently sold to. It is hard to get information on this. But we can see whether there is any evidence that neighborhoods in which a lot of council houses were sold between 1981 and 1991 had any dramatic change in their social composition. Table 9.11 presents some evidence on this. It regresses the change in the proportion of household heads in different social classes on differences in the proportions in different housing tenures. Social class I represents the high-

13. We do not have education data in the Survey of English Housing, but based on the 1984 LFS it is also clear that council house purchase was higher for more educated council tenants. Adding education variables to the first estimates column of table 9.10 using the ISCED classifications considered earlier produced probit marginals (standard errors) of .094 (.026) for household heads with ISCED 5-7,.061 (.013) for household heads with ISCED 3, and .026 $(.008)$ for household heads with ISCED 2 , relative to the low-education group ISCED $0-1$. 
Who Bought Their Council House? (probit models, marginal effects, and associated standard errors)

\begin{tabular}{|c|c|c|c|c|}
\hline & \multicolumn{2}{|c|}{ Excluding Social Class } & \multicolumn{2}{|c|}{ Including Social Class } \\
\hline & $\begin{array}{l}\text { Labour Force } \\
\text { Survey: } \\
\text { Buying } \\
1983-1984\end{array}$ & $\begin{array}{c}\text { Survey of } \\
\text { English Housing: } \\
\text { Buying since } \\
1990\end{array}$ & $\begin{array}{l}\text { Labour Force } \\
\text { Survey: } \\
\text { Buying } \\
1983-1984\end{array}$ & $\begin{array}{c}\text { Survey of } \\
\text { English Housing: } \\
\text { Buying since } \\
1990\end{array}$ \\
\hline Age of $\mathrm{HoH} 18-25$ & $-.069(.003)$ & $-.043(.003)$ & $-.068(.003)$ & $-.042(.003)$ \\
\hline Age of $\mathrm{HoH} 26-30$ & $-.035(.005)$ & $-.020(.005)$ & $-.037(.005)$ & $-.020(.004)$ \\
\hline Age of $\mathrm{HoH} 41-50$ & $.113(.006)$ & $.157(.005)$ & $.011(.006)$ & $.015(.005)$ \\
\hline Age of $\mathrm{HoH} 51-60$ & $.116(.006)$ & $.113(.006)$ & $.010(.006)$ & $.013(.006)$ \\
\hline Retired $\mathrm{HoH}$ & $.019(.008)$ & $.044(.006)$ & $.019(.008)$ & $.041(.006)$ \\
\hline Workless household & $-.078(.006)$ & $-.075(.006)$ & $-.071(.010)$ & $-.069(.006)$ \\
\hline Dual earner household & $.069(.008)$ & $.053(.007)$ & $.064(.008)$ & $.051(.007)$ \\
\hline Male $\mathrm{HoH}$ & $-.009(.007)$ & $-.006(.005)$ & $-.007(.007)$ & $-.003(.005)$ \\
\hline Nonwhite $\mathrm{HoH}$ & $-.018(.009)$ & $-.007(.006)$ & $-.017(.010)$ & $-.007(.006)$ \\
\hline Married, no kids & $.049(.011)$ & $.022(.006)$ & $.052(.011)$ & $.021(.006)$ \\
\hline Married, kids & $.085(.012)$ & $.046(.008)$ & $.087(.012)$ & $.045(.008)$ \\
\hline Lone parent & $.051(.012)$ & $.025(.007)$ & $.052(.013)$ & $.024(.007)$ \\
\hline Multiple family & $.071(.020)$ & $.057(.014)$ & $.074(.020)$ & $.057(.014)$ \\
\hline No. of kids & $-.005(.002)$ & $-.006(.002)$ & $-.005(.002)$ & $-.006(.002)$ \\
\hline Professional $\mathrm{HoH}$ & & & $.114(.049)$ & $.058(.028)$ \\
\hline Intermediate $\mathrm{HoH}$ & & & $.114(.022)$ & $.055(.011)$ \\
\hline Skilled nonmanual $\mathrm{HoH}$ & & & $.059(.018)$ & $.029(.009)$ \\
\hline Skilled manual $\mathrm{HoH}$ & & & $.051(.013)$ & $.028(.007)$ \\
\hline Partly skilled $\mathrm{HoH}$ & & & $.017(.011)$ & $.013(.007)$ \\
\hline No. of households & 14,799 & 19,627 & 14,730 & 19,557 \\
\hline
\end{tabular}

Note: $\mathrm{HoH}=$ head of household.

est social class and social class $\mathrm{V}$ the lowest. Because all household heads are allocated to one of the social classes, the coefficients in a given row sum to zero. Areas with the largest falls in council housing seem to have a larger fall in households in the highest social classes. This may be because those in the higher social classes were more likely to buy their council houses but that they then sold them on to people from lower social classes. However, the coefficients are small compared to those on the private rental proportion where neighborhoods with an increase in the proportion in private rental seem to have big increases in the fraction of households from the higher social classes. This evidence does not suggest that council house sales have transformed the social composition of neighborhoods.

\subsection{Conclusions}

There is little evidence of any dramatic trend in regional inequalities or regional mobility in the United Kingdom in the last twenty-five years. This is true whether one looks at aggregate regions or very small areas. It is im- 
Table 9.11

The Effect of Council House Sales on the Social Composition of Neighborhoods

\begin{tabular}{lccccc}
\hline & \multicolumn{5}{c}{ Change in Proportion in Social Class } \\
\cline { 2 - 6 } $\begin{array}{l}\text { Change in Proportion } \\
\text { of Households }\end{array}$ & $\mathrm{I}$ & $\mathrm{II}$ & $\mathrm{III}$ & IV & $\mathrm{V}$ \\
\hline In LA & .0149 & .0298 & .0023 & -.0560 & .0089 \\
& $(.0086)$ & $(.0160)$ & $(.0175)$ & $(.0130)$ & $(.0077)$ \\
In private rented & .0660 & .2516 & -.1863 & -.0977 & -.0335 \\
& $(.0217)$ & $(.0406)$ & $(.0443)$ & $(.0329)$ & $(.0196)$ \\
In HA & .0316 & -.0538 & .0195 & .0745 & .0772 \\
& $(.0268)$ & $(.0502)$ & $(.0547)$ & $(.0407)$ & $(.0242)$ \\
In job-related rent & .0185 & .0278 & .1850 & -.2961 & .0647 \\
& $(.0320)$ & $(.0598)$ & $(.0652)$ & $(.0484)$ & $(.0289)$ \\
In nonpermanent & .0274 & .0402 & .0924 & .1030 & -.0782 \\
& $(.0734)$ & $(.1373)$ & $(.1450)$ & $(.1113)$ & $(.0663)$ \\
No. of observations & 7,415 & 7,415 & 7,415 & 7,415 & 7,415 \\
$R^{2}$ & 0.11 & 0.11 & 0.10 & 0.10 & 0.11 \\
\hline
\end{tabular}

Notes: The dependent variable is the change in the proportion of household heads in each social class from 1981-1991, and the right hand side is the change in the proportion of households in different housing tenures. The sample are the wards that can be matched in 1981 and 1991.

portant to realize how stable the United Kingdom has been over a long period: Table 9.12 presents population shares for the period 1911-1991 and the overriding impression (certainly compared to the United States) is how little has changed. There has been variation in mobility rates in the past twenty years, but it has been more connected with the cycle. Perhaps this is not surprising: There are no very dramatic policy changes in this area that might have been expected to transform mobility in the United Kingdom. The largest change is the sale of council houses, but a realistic assessment would suggest that the impact of this change is likely to be very small.

One of the most striking features of the United Kingdom is that the graduate labor market appears to be, to a first approximation, well integrated (using the United States as a benchmark). Any spatial problems occur in the labor market for the less educated. We have suggested a number of reasons for why this might be the case. First, the act of going away to college might act to sever connections with the region in which one grew up and make one more open to the possibility of residential moves.

Second, we have suggested that speculative moves in search of work by the unemployed are extremely rare in the United Kingdom. Furthermore, they are likely to remain so, given the costs of moving and the difficulty of obtaining accommodation if one is without work. The fact that vacancies for low-skilled work tend to be concentrated on local labor markets, whereas those for graduates tends to be more national, makes it difficult for the less skilled to seek work in other regions. High unemployment through- 
Table 9.12

Population Shares, 1911-1991 (\%)

\begin{tabular}{lrrr}
\hline & 1911 & 1961 & 1998 \\
\hline North & 6.5 & 6.1 & 5.2 \\
Yorkshire and Humberside & 9.2 & 8.8 & 8.5 \\
East Midlands & 5.8 & 5.9 & 7.0 \\
East Anglia & 2.8 & 2.8 & 3.7 \\
Southeast & 27.5 & 30.9 & 31.0 \\
Southwest & 6.7 & 6.5 & 8.3 \\
West Midlands & 7.8 & 9.0 & 9.0 \\
Northwest & 13.4 & 12.4 & 10.8 \\
Wales & 5.7 & 5.0 & 4.9 \\
Scotland & 11.3 & 9.8 & 8.6 \\
Northern Ireland & 3.0 & 2.7 & 2.8 \\
Greater London & 17.0 & 15.1 & 12.1 \\
Inner London & 11.8 & 6.6 & 4.7 \\
Metropolitan areas (excl. London) & 16.5 & 22.1 & 18.8 \\
Principal metropolitan cities (excl, London) & 7.5 & 8.0 & 5.8 \\
Total population (thousands) & 42,190 & 52,807 & 59,237
\end{tabular}

out much of this period has also made it unnecessary for employers to seek low-skilled workers outside the local labor market. The strong cyclicality in regional mobility suggests the overall state of the labor market may also be important in easing flows, although, ironically, it is in times of recession that commentators get most agitated about regional inequalities. Thus, regional mobility may improve as labor markets tighten, and there is some evidence of increased regional mobility among the less skilled in recent years. This process could be helped if technology allowed the creation of a national list of vacancies.

Finally, the housing market may act as a deterrent to moves. Low-skilled workers tend to be concentrated in social housing, and tenants in that sector have very low rates of regional mobility. However, we have suggested that this may be as much to do with the characteristics of workers in this sector as the intrinsic effect of the sector itself. The removal of controls on private-rental housing has led to a rapid rise in rents but only a very small change in the use of it, so it does not seem likely that dramatic changes to the structure of the housing market will be able to transform the system. It is not clear that the obstacles to migration at the moment are substantial. The costs of moving house (estate agent fees and transaction taxes - stamp duty) are low by international standards. It may be that there is an incentive in the U.K. system to put a large fraction of one's wealth into one's own housing (MIRAS, the absence of capital gains taxation on the primary residence and the lack of taxation of imputed rental income from owneroccupation), and this does expose one to the risk of a bad shock in one's locality, making it difficult to move from a region in recession to one that is 
booming. But it is the most educated who are most affected by this, and it is for this group that there seems to be a national labor market and for whom the U.K. labor market seems to work well.

In terms of policy for reducing regional inequalities, there are a number of possible strategies. One would be to move people to the jobs. The most important step in doing this is to make it easier for the less skilled to search for and accept jobs in other regions. Providing a national database on Job Centre vacancies should help in this regard, and moves are being made in this direction.

The other approach is to try to move jobs to the people. There are two ways in which this might be done. The first, which has been the basis for much of British regional policy, has been to provide direct employment for low-skilled workers in depressed areas by building factories (in the past) or call centers (the current reality). One can think of this employment as being in the "traded goods sector," as the demand for a region's labor does not have to come from expenditure of people living in that region.

However, many of the low skilled are employed in sectors that are not traded across regions- for example, retail or restaurants or personal services. Demand for this type of labor has to come from expenditure within the region. The strategy proposed by Rogers and Power (2000) is to try to lure the highly educated back to depressed regions and then hope that the expenditure of these individuals is the demand for the labor of the unskilled. An area with depressed demand sees the best educated leave, resulting in a further reduction in the demand for low-skilled labor.$^{14}$ The appropriateness of these two strategies does depend on the extent to which the low skilled are employed in traded goods sectors and the fraction of the expenditure of the highly skilled that is within the region where they live. These are interesting questions for further research.

\section{References}

Blackaby, D., and D. N. Manning. 1990. North-South divide: Questions of existence and stability. Economic Journal 100:510-527.

Blanchard, O., and L. Katz. 1992. Regional evolutions. Brookings Papers on Economic Activity, Issue no. 1:1-75. Washington, D.C.: Brookings Institution.

Boheim, R., and M. Taylor. 2000. Residential mobility, housing tenure, and the labour market in Britain. University of Essex, Institute for Social and Economic Research. Unpublished Manuscript.

14. The metropolitan areas (excluding London) do have lower than average shares of the well educated in the population, suggesting there may be something in this, although London has the highest proportion of graduates and some of the lowest employment rates among the less educated. 
Cabinet Office. 1999. Sharing the nation's prosperity: Variation in economic and social conditions across the UK. London: Cabinet Office.

Cameron, G., and J. Muellbauer. 1998. The housing market and regional commuting and migration choices. Scottish Journal of Political Economy 45:420-446.

_ 2000. Earnings biases in the United Kingdom Regional Accounts: Some economic policy and research implications. Economic Journal 110: F412-419.

Davies, N. 1998. Dark heart: The shocking truth about modern Britain. London: Vintage Press.

Decressin, J., and A. Fatas. 1995. Regional labor market dynamics in Europe. European Economic Review 39:1627-655.

Duranton, G., and V. Monastiriotis. 2000. Mind the gaps: The evolution of regional inequalities in the UK. The London School of Economics and Political Science, Department of Geography and Environment. Mimeograph.

Ehrenreich, B. 2001. Nickel and dimed: Undercover in low-wage USA. New York: Henry Holt.

Evans, P., and B. McCormick. 1994. The new pattern of regional unemployment: Causes and policy significance. Economic Journal 104:633-647.

Greenwood, M. J. 1997. Internal Migration in developed countries. In Handbook of population economics and family economics, ed. M. R. Rosenzweig and O. Stark, 647-720. Amsterdam: North-Holland.

Henley, A. 1998. Residential mobility, housing equity and the labour market. Economic Journal 108:414- 427.

Hoynes, H. 1999. The employment, earnings and income of less skilled workers over the business cycle. In Finding jobs, ed. R. Blank and D. Card, 23-71. Chicago: University of Chicago Press.

Hughes, G., and B. McCormick. 1981. Do council housing policies reduce migration between regions? Economic Journal 91:919-937.

- 1985. Migration intentions in the UK: Which households want to migrate and which succeed? Economic Journal 95:113-123.

1987. Housing markets, unemployment and labour market flexibility in the UK. European Economic Review 31:615-645. 527.

1994. Is migration narrowing the North-South divide? Economica 61:509-

. 2000. Housing policy and labour market performance. University of Southampton, report for the U.K. Department of the Environment, Transport, and Regions.

Jackman, R., and S. Savouri. 1992. Regional migration in Britain: An analysis of gross flows using NHS central register data. Economic Journal 102:1433-450.

McCormick, B. 1997. Regional unemployment and labour mobility in the UK. European Economic Review 41:581-589.

Mincer, J. 1978. Family migration decisions. Journal of Political Economy 86:749773.

Muellbauer, J., and A. Murphy. 1997. Booms and busts in the UK housing market. Economic Journal 107:1701-727.

Noble, M., C. Dibben, G. Smith, and M. Evans. 2000. How have poor areas changed in the 1990s? Oxford University, Social Disadvantage Research Group. Unpublished Manuscript.

Oswald, A. 1996. A conjecture on the explanation for high unemployment in the industrialized nations: Part I. University of Warwick, Department of Economics. Unpublished Manuscript.

- 1997. Theory of homes and jobs. University of Warwick, Department of Economics. Unpublished Manuscript. 
Pissarides, C., and J. Wadsworth. 1989. Unemployment and the inter-regional mobility of labour. Economic Journal 99:739-755.

Rogers, R., and A. Power. 2000. Cities for a small country. London: Faber and Faber.

United Kingdom, Department of the Environment, Transport, and Regions. 1999. Housing benefit and the private landlords. London: Department of the Environment, Transport, and Regions.

- 2000. Quality and choice: A decent home for all: A green paper. London: Department of the Environment, Transport, and Regions, April. 